Geochimica et Cosmochimica Acta

September 2017, Volume 212, Pages 99-118

http://dx.doi.org/10.1016/i.gca.2017.06.011

http://archimer.ifremer.fr/doc/00388/49956/

(C) 2017 Elsevier Ltd. All rights reserved.

\title{
The isotope composition of inorganic Germanium in seawater and deep sea sponges
}

\author{
Guillermic Maxence ${ }^{1}$, Lalonde Stefan ${ }^{1}$, Hendry Katharine R. ${ }^{2}$, Rouxel Olivier ${ }^{3,4,{ }^{*}}$
}

${ }^{1}$ Institut Universitaire Européen de la Mer, Laboratoire Domaines Océaniques UMR 6538, Université de Brest, BP 80 F- 29280 Plouzané, France

${ }^{2}$ School of Earth Science, University of Bristol, Wills Memorial Building, Queen's Road, Bristol BS8 IRJ, UK

${ }^{3}$ IFREMER, Centre de Brest, Unité Géosciences Marines, 29280 Plouzané, France

${ }^{4}$ University of Hawaii, Department of Oceanography, Honolulu, HI 96822, USA

* Corresponding author : Maxence Guillermic, email address : orouxel@hawaii.edu

\begin{abstract}
:
Although dissolved concentrations of germanium $(\mathrm{Ge})$ and silicon $(\mathrm{Si})$ in modern seawater are tightly correlated, uncertainties still exist in the modern marine Ge cycle. Germanium stable isotope systematics in marine systems should provide additional constraints on marine Ge sources and sinks, however the low concentration of $\mathrm{Ge}$ in seawater presents an analytical challenge for isotopic measurement. Here, we present a new method of pre-concentration of inorganic Ge from seawater which was applied to measure three $\mathrm{Ge}$ isotope profiles in the Southern Ocean and deep seawater from the Atlantic and Pacific Oceans. Germanium isotopic measurements were performed on Ge amounts as low as $2.6 \mathrm{ng}$ using a double-spike approach and a hydride generation system coupled to a MC-ICP-MS. Germanium was co-precipitated with iron hydroxide and then purified through anion-exchange chromatography. Results for the deep (i.e. > $1000 \mathrm{~m}$ depth) Pacific Ocean off Hawaii (nearby Loihi Seamount) and the deep Atlantic off Bermuda (BATS station) showed nearly identical $\delta 74 / 70 \mathrm{Ge}$ values at $3.19 \pm 0.31 \%$ ( $2 \mathrm{SD}, \mathrm{n}=9)$ and $2.93 \pm 0.10 \%(2 \mathrm{SD}, \mathrm{n}=2)$, respectively. Vertical distributions of Ge concentration and isotope composition in the deep Southern Ocean for water depth $>1300 \mathrm{~m}$ yielded an average $\delta 74 / 70 \mathrm{Ge}=3.13 \pm 0.25 \%$ o $(2 \mathrm{SD}, \mathrm{n}=14)$ and $\mathrm{Ge} / \mathrm{Si}=0.80 \pm 0.09$ $\mu \mathrm{mol} / \mathrm{mol}(2 \mathrm{SD}, \mathrm{n}=12$ ). Significant variations in $\delta 74 / 70 \mathrm{Ge}$, from 2.62 to $3.71 \%$, were measured in the first $1000 \mathrm{~m}$ in one station of the Southern Ocean near Sars Seamount in the Drake Passage, with the heaviest values measured in surface waters. Isotope fractionation by diatoms during opal biomineralization may explain the enrichment in heavy isotopes for both $\mathrm{Ge}$ and $\mathrm{Si}$ in surface seawater. However, examination of both oceanographic parameters and $\delta 74 / 70 \mathrm{Ge}$ values suggest also that water mass mixing and potential contribution of shelf-derived $\mathrm{Ge}$ also could contribute to the variations. Combining these results with new $\mathrm{Ge}$ isotope data for deep-sea sponges sampled nearby allowed us to determine a Ge isotope fractionation factor of $-0.87 \pm 0.37 \%$ ( $2 \mathrm{SD}, \mathrm{n}=12$ ) during $\mathrm{Ge}$ uptake by sponges. Although $\mathrm{Ge}$ has long been considered as a geochemical twin of $\mathrm{Si}$, this work underpins fundamental differences in their isotopic behaviors both during biomineralization processes and in their oceanic distributions. This suggests that combined with $\mathrm{Si}$ isotopes, $\mathrm{Ge}$ isotopes hold significant promise as a complementary proxy for delineating biological versus source effects in the evolution of the marine silicon cycle through time.
\end{abstract}

Keywords : stable isotopes, germanium, silicon, sponges, Southern Ocean, chemical oceanography 


\section{Introduction}

Germanium $(\mathrm{Ge})$ has long been considered a pseudo-heavy isotope of silicon ( $\mathrm{Si})$ because it displays similar behavior in marine and terrestrial environments (Froelich and Andreae, 1981). Dissolved inorganic Ge concentrations in seawater range from 0 to about $200 \mathrm{pM}$ and display a correlation with dissolved silica that is remarkably consistent across the world's oceans, underlying its potential as a complementary tracer for marine silicon cycling (Froelich and Andreae, 1981; Froelich et al., 1985a; Froelich et al., 1985b; Ellwood and Maher, 2003). Relatively constant Ge/Si ratios of $0.76 \mu \mathrm{mol} / \mathrm{mol}$ in seawater worldwide suggest that $\mathrm{Ge} / \mathrm{Si}$ is not fractionated during biological uptake (Murnane and Stallard, 1988; Froelich et al., 1989), although a preferential uptake of Si versus Ge has been observed at low Si concentrations $(<6 \mu \mathrm{M})$ (Ellwood and Maher, 2003).

It has been generally thought that oceanic $\mathrm{Ge} / \mathrm{Si}$ ratios reflect primarily the $\mathrm{Ge} / \mathrm{Si}$ ratios of the different sources and sinks of $\mathrm{Ge}$ and $\mathrm{Si}$ in seawater. Seafloor hydrothermal vent fluids at mid-ocean ridges, ridge flanks and volcanic seamounts have Ge/Si ratios of 8 to 14 $\mu \mathrm{mol} / \mathrm{mol}$ (Mortlock and Froelich, 1987; Wheat and McManus, 2008; Escoube et al., 2015) whereas $\mathrm{Ge} / \mathrm{Si}$ ratios in rivers are about $0.54 \mu \mathrm{mol} / \mathrm{mol}$, with significant temporal and spatial variations $(0.1$ to $2.5 \mu \mathrm{mol} / \mathrm{mol})$ that depend on weathering regimes (Mortlock and Froelich, 1987; Kurtz et al., 2011). Ge/Si in rivers is depressed relative to bulk continental crust (Ge/Si $=1.3 \mu \mathrm{mol} / \mathrm{mol}$ ) due to the affinity of Ge for iron oxyhydroxides, organic compounds and secondary soil silicates (Kurtz et al., 2002). The elevated Ge/Si ratio of seafloor hydrothermal fluids is likely the result of mineral-fluid partitioning in the reaction zone and the subsurface precipitation of silicate minerals that fractionate against Ge (Mortlock et al., 1993; Pokrovski and Schott, 1998; Escoube et al., 2015). While the major sink of Si in seawater is the burial of biogenic opal in sediments, mass balance of $\mathrm{Ge}$ in seawater requires the existence of a nonopal sink, probably associated with an Fe-rich authigenic sink (Hammond et al., 2000; King et al., 2000; McManus et al., 2003; Baronas et al., 2016).

Capitalizing on the promise of the $\mathrm{Ge} / \mathrm{Si}$ proxy, several studies have explored the use of Ge isotope ratios [defined as $\delta^{74 / 70} \mathrm{Ge}=1000 *\left({ }^{74} \mathrm{Ge} /{ }^{70} \mathrm{Ge}_{\text {sample }} /{ }^{74} \mathrm{Ge} /{ }^{70} \mathrm{Ge}_{\text {NIST3120a }}\right.$ - 1) as a new geochemical tracer of Ge sources and behavior in oceanic environments and hydrothermal systems (Rouxel et al., 2006; Siebert et al., 2006; Qi et al., 2011; Siebert et al., 2011; Escoube et al., 2012; Belissont et al., 2014; Escoube et al., 2015). Based on the Ge isotope composition of modern marine biogenic opal (e.g. sponges and diatoms), previous 
studies have suggested that the Ge isotopic composition of seawater is enriched in heavy isotopes relative to the oceanic crust by up to $2.5 \%$ (Mantoura, 2006; Rouxel et al., 2006). This indirect estimation of the Ge isotope composition of seawater has been used to establish a preliminary isotopic mass balance for Ge in seawater (Escoube et al., 2015). However, due to analytical challenges, the Ge isotopic composition of seawater - and the driving mechanisms behind isotopic fractionation in the marine system - remain unknown. Considering the wealth of previous studies investigating the variations of $\mathrm{Si}$ isotopes in seawater (Reynolds et al., 2006; Grasse et al., 2013; de Souza et al., 2014; Cao et al., 2015), the study of Ge isotope systematics in seawater has strong potential both in terms of assessing the global budget of $\mathrm{Ge}$ in seawater and also as an oceanographic proxy that could be used in conjunction with $\mathrm{Si}$ isotopes to better understand changes in silicon cycling.

Here, we report a method for the pre-concentration and Ge isotope analysis of dissolved inorganic Ge in seawater using online hydride-generation coupled to multicollector inductively coupled plasma mass spectrometry (MC-ICP-MS). This method is adapted from techniques described previously (Rouxel et al., 2006; Siebert et al., 2006; Siebert et al., 2011; Escoube et al., 2012) and involves: (1) the addition of Ge double-spike $\left({ }^{73} \mathrm{Ge},{ }^{70} \mathrm{Ge}\right)$ to correct for both instrumental mass bias and Ge isotope fractionation during sample preparation; (2) pre-concentration of inorganic Ge by co-precipitation with iron hydroxide $\left(\mathrm{Fe}(\mathrm{OH})_{3}\right),(3)$ recovery and dissolution of $\mathrm{Fe}(\mathrm{OH})_{3}$ followed by anion-exchange chromatographic purification of Ge, (4) gaseous hydride introduction into the plasma torch allowing for high sensitivity and aqueous matrix-free isotope analysis. We applied this method to obtain the first Ge isotope profiles in seawater using a set of samples from the Southern Ocean that were previously investigated for Si isotopes (Hendry et al., 2010). We also report new measurements of deep seawater from the Atlantic and Pacific Oceans. By comparing $\delta^{74 / 70} \mathrm{Ge}$ from sponges and co-located seawater, we also determined the potential influence of biological uptake on fractionation of $\mathrm{Ge}$ isotopes and $\mathrm{Ge} / \mathrm{Si}$.

\section{Materials and methods}

\subsection{Sample collection}

Seawater samples and sponges from the Southern Ocean were collected in May 2011 from the Drake Passage (Southern Ocean) aboard the $R / V$ Nathaniel B. Palmer. Seawater 
samples were obtained at three stations; "Sars" $\left(59.753^{\circ} \mathrm{S}, 69.057^{\circ} \mathrm{W}\right.$; bottom depth at 3141 m) nearby the Sars seamount, "Burdwood Bank" $\left(55.054^{\circ} \mathrm{S}, 62.100^{\circ} \mathrm{W}\right.$; bottom depth at 4191 $\mathrm{m}$ ), and West Antarctic Peninsula (WAP) off Slope $\left(62.067^{\circ} \mathrm{S}, 62.583^{\circ} \mathrm{W}\right.$; bottom depth at $4726 \mathrm{~m}$ ) (Fig. 1). Sampling depths ranged from 2.8 to $3100 \mathrm{~m}$ for "Sars", 501 to $4110 \mathrm{~m}$ for "Burdwood Bank" and 4.7 to 4718 m for "WAP". Hence, surface seawater was sampled only at two stations. The samples were collected in Niskin bottles during the deep water CTD casts, filtered through $0.4 \mu \mathrm{m}$ Supor membranes (Pall acropak filters) and stored in precleaned 4 L HDPE bottles. The seawater samples were acidified immediately with hydrochloric acid (Optima grade) to reach a final concentration of $0.1 \% \mathrm{v} / \mathrm{v}$ and stored until further processing in April 2015. Inorganic $\mathrm{Si}(\mathrm{OH})_{4}$ (referred to as $\mathrm{Si}$ in this paper) concentration analyses of seawater were carried out at Woods Hole Oceanographic Institution and have been previously reported in Hendry et al. (2010).

Sponge samples were obtained from living specimens previously investigated for their Si and Zn isotope signatures (Hendry et al., 2010; Hendry and Andersen, 2013). We selected samples from a north-south transect across the Scotia Sea and Drake Passage, with additional samples from the Scotia Sea, encompassing a range of bottom-water Si concentrations (12 to $120 \mu \mathrm{M}$ ) and depths (320 to $2266 \mathrm{~m}$ ). Sponges were collected aboard the $R / V$ Nathaniel $B$. Palmer (April-May 2008) by either benthic trawl or dredge, and were subsequently stored dried or frozen.

Surface and deep seawater samples from the North Atlantic were obtained from the GEOTRACES IC1 BATS Atlantic intercalibration station $\left(31.667^{\circ} \mathrm{N} ; 64.167^{\circ} \mathrm{W}\right)$ (Boyle et al., 2012). Although Ge is not considered strictly as contamination-prone element, we selected these samples for documenting potential analytical bias using regular Niskins bottles versus GEOTRACES-compliant rosettes. This set of samples also allows future interlaboratory comparison of seawater Ge isotope values. The GEOTRACES Surface Isotope (GSI) sample was obtained from a $4 \mathrm{~L}$ split of a $~ 500 \mathrm{~L}$ tank filled with near surface ( $7 \mathrm{~m}$ ) water pumped from the UCSC towed fish. The GEOTRACES Deep Isotope (GDI) sample was obtained from a $4 \mathrm{~L}$ split of a $\sim 250 \mathrm{~L}$ tank filled from all $24 \mathrm{GO}-F l o$ bottles on the US GEOTRACES trace metal rosette at $2000 \mathrm{~m}$. All samples were filtered on-board at $0.2 \mu \mathrm{m}$ using Pall Acropak capsule filters and stored acidified at $\mathrm{pH} 1.8$ with purified $6 \mathrm{M}$ $\mathrm{HCl}$.

Deep seawater from the Pacific Ocean was obtained from 3 stations: FeMO Deep

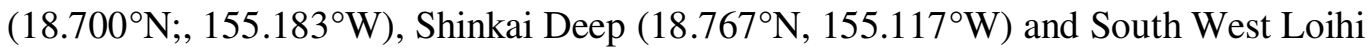


$\left(18.867^{\circ} \mathrm{N}, 155.300^{\circ} \mathrm{W}\right)$. Samples from FeMO Deep were recovered during the cruise FeMO 2009 (R/V Kilo Moana) in October 2009, southeast of the Loihi Seamount (Edwards et al., 2011). Samples from Shinkai Deep and SW Loihi were recovered during the cruise Loihi 2014 ( $R /$ V Falkor) in July 2014 at the base and around the summit of the Loihi Seamount, respectively. All seawater samples were collected by CTD rosette using 12 L Niskin bottles internally sprung with silicone. Although Loihi Seamount is known for having significant hydrothermal activity at its summit with westward dispersal of a hydrothermal plume containing high concentrations of Fe (Bennett et al., 2011) and potentially Ge (Escoube et al., 2015), we selected samples from areas and water-depths that were removed from the hydrothermal plume (i.e. absence of Fe and Mn anomalies). Because the typical sample size was limited to $1 \mathrm{~L}$, we pooled several samples from a similar range of water depths to obtain sample sizes of 3.5 to $4 \mathrm{~L}$. Hence, for these samples, only the depth range is reported. We analyzed both filtered (through $0.2 \mu \mathrm{m}$ Supor filters) and unfiltered samples that were acidified to $\mathrm{pH} 1.8$ with $6 \mathrm{M} \mathrm{HCl}$ (optima grade; Fisher Chemical) prior to analysis.

Large volumes of coastal surface seawater were used for the initial stages of analytical development related to Ge pre-concentration and isotope analysis. This internal standard was obtained from the Bay of Brest in March 2015. It was filtered to $0.45 \mu \mathrm{m}$ and acidified to $\mathrm{pH}$ 2 using concentrated single distilled hydrochloric acid.

\subsection{Reagents and germanium standard solutions}

The NIST SRM 3120a elemental standard solution (Lot \#000411, $10 \mathrm{mg} / \mathrm{g}$ ) is used in this study as a Ge reference standard, and has been calibrated against other internal standards used in previous Ge isotope studies (Escoube et al., 2012). We used the same double-spike previously employed by Escoube et al. $(2012 ; 2015)$, prepared from Ge metal spikes ${ }^{73} \mathrm{Ge}$ and

${ }^{70} \mathrm{Ge}$ purchased from Isoflex USA (Ge-70 \#32-01-70-3259 and Ge-73 \#32-01-73-1405). Each spike was dissolved separately and we obtained the following composition for the doublespike: ${ }^{74} \mathrm{Ge} /{ }^{70} \mathrm{Ge}=0.07614 \pm 0.00010 ;{ }^{73} \mathrm{Ge} /{ }^{70} \mathrm{Ge}=0.60707 \pm 0.00008 ;{ }^{72} \mathrm{Ge} /{ }^{70} \mathrm{Ge}=0.05626$ \pm 0.00008 (2sd uncertainties).

Iron(III) solution used for Ge co-precipitation was prepared by dissolution of $\mathrm{FeCl}_{3} \cdot 6 \mathrm{H}_{2} \mathrm{O}$ salt (Acros Organics) in $6 \mathrm{M} \mathrm{HCl}$ (single distilled $\mathrm{HCl}$ ). In order to decrease reagent blanks, the solution was evaporated at $120^{\circ} \mathrm{C}$ to remove $\mathrm{Ge}$ impurities by the 
formation of volatile $\mathrm{GeCl}_{4}$ species (Kaya and Volkan, 2011; Luais, 2012). The stock Fe(III) solution was adjusted to a Fe concentration of $12,000 \mathrm{ppm}$ in $3 \mathrm{M} \mathrm{HCl}$.

The hydride generation reagent was made of $10 \mathrm{~g}$ of sodium borohydride powder (high purity $\mathrm{NaBH}_{4}$; Fisher Chemical) and $5 \mathrm{~g}$ of sodium hydroxide pellets (analytical grade; Acros Organics) dissolved in $1 \mathrm{~L}$ of ultrapure water (Milli-Q $18.2 \mathrm{M} \Omega \cdot \mathrm{cm}$ ) and was prepared freshly before each analytical session. During chemical dissolution and purification, high purity $\mathrm{HNO}_{3}$ (distilled grade) and $\mathrm{HF}$ (optima grade; Fisher Chemical) were used.

\subsection{Preconcentration of inorganic Ge from seawater}

The double-spike $\left({ }^{70} \mathrm{Ge}\right.$ and $\left.{ }^{73} \mathrm{Ge}\right)$ was first added to the sample bottle to a spike/natural weight ratio, referred hereafter as s/n, of about 1.0. Although Escoube et al. (2012) showed that Ge isotope measurements are still acceptable with a s/n ratio ranging from 0.4 to 8 , we found that a narrower $\mathrm{s} / \mathrm{n}$ ratio of 0.7 to 1.3 provided optimal analytical conditions. Hence, this method requires the prior knowledge of Ge concentration in the samples. In practice, the natural concentration of Ge was estimated by using the average Ge/Si ratio for seawater and known Si concentrations (or water depth). The double-spike was added to the acidified seawater samples and left to equilibrate for at least 2 hours.

Experiments done with longer equilibration time revealed no effect on the isotopic value or Ge recovery.

About $4 \mathrm{~mL}$ of Fe(III) solution at 12,000 ppm Fe was added per liter of seawater, in order to obtain a final solution of about $12 \mathrm{mg} \mathrm{Fe} / \mathrm{L}$, and left to equilibrate for two hours. The solution $\mathrm{pH}$ was then increased to $\mathrm{pH} 8 \pm 0.3$ with concentrated optima-grade ammonia $\left(\mathrm{NH}_{4} \mathrm{OH}\right)$ solution at $14 \mathrm{M}$. Germanium co-precipitation with Fe hydroxides is achieved after 100 min (Pokrovsky et al., 2006). Analytical-grade $\mathrm{NaOH}$ solution at $8 \mathrm{M}$ was used in the initial stage of the experimental development but was discontinued due to significant blank contribution. A contamination of $\mathrm{Ge}$ in the $\mathrm{NaOH}$ pellets was suspected. The solution was left for at least 12 hours to flocculate. Then, the supernatant was siphoned off and the remaining slurry was transferred into $50 \mathrm{~mL}$ centrifuge tubes. Fe-oxyhydroxide precipitates were finally recovered after centrifugation at $1500 \mathrm{G}$ for 4 minutes. The solid residue was then processed as other mineral or biogenic opal samples as described below.

\subsection{Sponge spicule preparation}


Preparation of the modern sponge spicules followed the protocol described in Hendry et al. (2010) for the measurements of Si isotopes, and was carried out in the Department of Earth Sciences, Oxford University. The modern spicules were initially separated from organic matter by repeatedly heating and sonicating in concentrated $\mathrm{HNO}_{3}$ and $30 \% \mathrm{H}_{2} \mathrm{O}_{2}$. Sediment grains were removed by picking until visual inspection showed the spicules to be clear of detritus. The spicules were then additionally cleaned of any remaining organic matter and surface contaminants using three steps: 1) reductive cleaning using hydroxylamine chloride $(0.1 \%)$ /acetic acid solution $(1 \%), 2)$ etching with sodium fluoride $(0.1 \% \mathrm{NaF})$ and 3) oxidation with a strong acid solution $\left(50 \% \mathrm{HNO}_{3}: \mathrm{HCl}\right.$, in-house distilled) following previous methods (Ellwood et al., 2006).

\subsection{Digestion and chromatographic separation}

The method used in this study was derived from that used for Ge isotope analysis in rocks and minerals developed in Rouxel et al. (2006). Both Fe-oxyhydroxide precipitates and biogenic opal (avg. 50 and $25 \mathrm{mg}$, respectively) were dissolved with $1 \mathrm{~mL}$ of concentrated HF in Teflon beaker, after addition of an appropriate quantity of Ge double-spike in the case of biogenic opal. Samples were left for 2 hours on a hotplate at $90^{\circ} \mathrm{C}$ until dissolution was complete. The samples were then left to cool at room temperature and then diluted to $1 \mathrm{M} \mathrm{HF}$ using Milli-Q water.

An anion-exchange resin (AG1-X8, Bio-Rad, Hercules, CA, USA) was used for the separation of $\mathrm{Ge}$ from $\mathrm{Fe}$ and other matrix elements and isobaric interferences that could form volatile hydride (e.g. Se). A total of $24 \mathrm{LDPE}$ columns were filled with $1.8 \mathrm{~mL}$ of resin (wet volume) and cleaned with $10 \mathrm{~mL}$ washes of $3 \mathrm{M} \mathrm{HNO}_{3}, 0.28 \mathrm{M} \mathrm{HNO}_{3}$ and Milli-Q water, before being conditioned with $5 \mathrm{~mL}$ of $1 \mathrm{M} \mathrm{HF}$. The sample was loaded and fluorinated Ge was strongly adsorbed on the resin. $5 \mathrm{~mL}$ of $1 \mathrm{M} \mathrm{HF}$ was used to elute most of the elements of the initial matrix followed by $3 \mathrm{~mL}$ of Milli-Q water. Finally, Ge was eluted with $10 \mathrm{~mL}$ of $0.28 \mathrm{M} \mathrm{HNO}_{3}$. The solution was recovered, evaporated to dryness on a hotplate at $80^{\circ} \mathrm{C}$ and re-dissolved in a precise volume of $0.28 \mathrm{M} \mathrm{HNO}_{3}$ so that all samples attained an identical final Ge concentration (typically $5 \mathrm{ppb}$ ) for isotope analysis by hydride generation MC-ICP-MS.

\subsection{Hydride generation (HG) MC-ICP-MS analysis}


All measurements were carried out on a Thermo Scientific instrument MC-ICP-MS Neptune (PSO-IFREMER) with similar operating conditions as described in Escoube et al. (2012). An online hydride generation system (CETAC, HGX-200) was used to generate Ge hydride by mixing the Ge sample solution with $\mathrm{NaBH}_{4}$ solution. This system is similar to previous studies (Rouxel et al., 2006) as it used two Argon inlets to transport Ge hydride and stabilize signal intensity, and an on-line PTFE filter to prevent aerosols from reaching the plasma. The sample and $\mathrm{NaBH}_{4}$ solutions were introduced at the same flow rate of about 150 $\mu \mathrm{l} / \mathrm{min}$ and were mixed in a $10 \mathrm{~cm}$-long reaction coil before entering the gas-liquid separator.

The Neptune instrument was operated in low mass resolution mode, and ${ }^{70} \mathrm{Ge},{ }^{72} \mathrm{Ge}$, ${ }^{73} \mathrm{Ge}$ and ${ }^{74} \mathrm{Ge}$ were measured on L2, C, H1 and H2 cups, whilst ${ }^{68} \mathrm{Zn},{ }^{69} \mathrm{Ga},{ }^{71} \mathrm{Ga}$ and ${ }^{77} \mathrm{Se}$ were also monitored on L4, L3, L1 and $\mathrm{H} 4$ cups. The isotope ${ }^{76} \mathrm{Ge}$ was not measured because of a major interference from ${ }^{38} \mathrm{Ar}_{2}$. The NIST 3120a standard solution was measured with the same instrumental set-up before and after each sample analysis. Each analysis consisted of 5 blocks of 6 measurements ( 2 seconds integration time per measurement). The Ge isotope composition of each block of measurements was calculated using the double-spike data reduction scheme presented in Siebert et al. (2001) for Mo isotopes. Data for each sample were then processed by removing the $5 \%$ most extreme $\delta^{74 / 70} \mathrm{Ge}$ values (outside 2SD) and normalized to average NIST 3120a values measured before and after the sample. The internal error was reported as two standard errors $(2 \mathrm{SD} / \sqrt{ } \mathrm{n})$ calculated using 5 blocks of 6 measurements each. External precision (as 2SD) of the sample was determined by calculating the standard deviation of all NIST 3120a standards measured during the same analytical session.

\section{Results}

\subsection{Procedural blank and Ge recovery from seawater}

During the initial stage of the analytical development, we observed significant contamination of the pure Fe(III) salt used for Ge co-precipitation of approximately $0.1 \mathrm{ng}$ Ge per $\mathrm{mg}$ of Fe. Considering that up to $200 \mathrm{mg}$ of Fe(III) was used per sample, this level of Ge blank precluded the analysis of Ge-depleted surface seawater. After further evaporation of the Fe(III) solution in $6 \mathrm{M} \mathrm{HCl}$, Ge blanks were lowered to $0.01 \mathrm{ng} / \mathrm{mg} \mathrm{Fe}$. The procedural blanks were determined for each sample set by processing 1 to $4 \mathrm{~L}$ of spiked ultrapure water 
as an unknown sample. We determined an overall procedural blank ranging from $0.5 \mathrm{ng}$ to as low as $0.1 \mathrm{ng}$, which may be either resulting from Ge impurities in both the $\mathrm{Fe}(\mathrm{III})$ solution and the $\mathrm{NaOH}$ or $\mathrm{NH}_{4} \mathrm{OH}$ used to raise the $\mathrm{pH}$ for the co-precipitation step. This corresponds to an equivalent $\mathrm{Ge}$ concentration in seawater of 4L-size seawater ranging from $1.8 \mathrm{pM}$ to 0.2 pM. By comparison, Ge blanks determined for the chromatographic separation only were below the detection limit of $0.01 \mathrm{ng}$, and therefore negligible. For surface seawater, the total amount of Ge recovered from a 4L-size sample was about $6 \mathrm{ng}$, so a maximum of $0.5 \mathrm{ng}$ blank would correspond to up to $25 \%$ of the measured signal, which requires careful examination of its effect on $\mathrm{Ge}$ isotope composition. Several lines of evidences suggest that blank contamination did not affect significantly our surface seawater measurement within analytical uncertainty. First, the comparison between surface and deep seawater at BATS (Table 1) and deep Pacific seawater yielded similar $\delta^{74 / 70}$ Ge at $3.1 \pm 0.3 \%$ o despite significant concentration differences (from $7 \mathrm{pM}$ to $117 \mathrm{pM}$ ). We also did not observe any positive correlation between Ge/Si and Ge concentration in Ge-depleted surface seawater (Table 2), which would be expected if significant amounts of Ge were derived from blank contamination. We also attempted to measure the Ge isotope composition of the procedural blank and obtained a $\delta^{74 / 70} \mathrm{Ge}$ value of $1.6 \pm 0.2 \%$ or for quantity of $0.4 \mathrm{ng}$, which is within the range of natural Ge composition (e.g. between crustal and seawater values). For deep seawater with Ge concentrations above $50 \mathrm{pM}$, the blanks were in all cases negligible with a contribution of less than $3 \%$ of the total measured signal.

Although the use of Ge double-spike should correct for potential Ge isotope mass fractionation in the case of incomplete recovery, we evaluated a range of co-precipitation conditions in order to optimize Ge recovery and decrease the overall sample size. It is expected that the recovery yield of Ge using the Fe co-precipitation technique would be dependent on the final sample $\mathrm{pH}$, the amount of Fe-oxyhydroxide in suspension, and the overall kinetics of Ge adsorption. Figure 2 presents the effect of $\mathrm{pH}$ and different iron additions on the Ge yield. Maximum adsorption of Ge occurred between $\mathrm{pH} 6$ and 8, regardless of the quantity of Fe(III) added to seawater. These results are generally consistent with the study of Pokrovsky et al. (2006), who found a maximum adsorption of Ge at pH between 6 and 9. However, the yields were lower in our study, and ranged from $70 \%$ to $>90$ $\%$ which is probably explained by the much lower Fe concentration (i.e. about 1000-fold) used for Fe coprecipitation compared to the experimental study of Pokrovsky et al. (2006). Iron oxides are also known to co-precipitate a range of trace elements including oxyanions 
and trace metals (e.g. Martinez and McBride, 1998; Raven et al., 1998). Although competition between germanium and other solutes may occur during co-precipitation, we found no significant correlation between yield and nutrient concentrations or depth.

\subsection{Determination of analytical accuracy and potential effects of methylated Ge species}

We evaluated the accuracy of the analytical procedure using a standard addition method, similar to Rouxel et al. (2006), whereby incremental quantities of the Ge isotope standard was added to an unknown sample. This method allows the robust determination of the Ge concentration and Ge isotope composition of an unknown sample, and whether any changes in the initial matrix-to-analyte ratio causes any analytical artifacts or residual interferences. We used several aliquots of our internal seawater samples from the Bay of Brest, which were doped with various amounts of the Ge NIST 3120a standard. The composite samples were spiked and processed through the same chemical procedure as unknown samples. The Ge concentration and Ge isotope composition of these composite samples are presented in Fig. 3 along with two independent measurements of the pure seawater sample. The relationship between $\delta^{7 / 70} \mathrm{Ge}$ and $\mathrm{Ge}$ concentration values for the composite sample and the percentage of Ge added follows the predicted mixing relationship, with a $\delta^{74 / 70} \mathrm{Ge}$ value for Bay of Brest surface water estimated at $2.54 \pm 0.41 \%$ (2SE) and with a Ge concentration of 7.4 $\pm 0.8 \mathrm{pM}(2 \mathrm{SE})$. By comparison, the two independent $\mathrm{Ge}$ isotopic measurements of Bay of Brest yielded $\delta^{74 / 70} \mathrm{Ge}$ value of $2.42 \pm 0.07 \%$ (2SE) and $2.27 \pm 0.16 \%$ o (2SE), which are indistinguishable within uncertainty of the calculated value above, thus confirming the accuracy of the method.

Because organometallic Ge species exist in seawater in methyl-Ge (MMGe) and dimethyl-Ge (DMGe) forms (Lewis et al., 1985; Lewis et al., 1989), representing more than $70 \%$ of the total $\mathrm{Ge}$ in the ocean, care should be taken to avoid the recovery of these species during chemical preconcentration of inorganic Ge. The vertical profiles of MMGe and DMGe in seawater typically show vertically homogeneous concentrations for both species within analytical error of $340 \pm 7$ pM MMGe and $110 \pm 3$ pM DMGe (Lewis et al., 1985). Hence, the sum of methylated Ge species in our surface seawater sample from the Bay of Brest is expected to be about $450 \mathrm{pM}$, which is several orders of magnitude higher than the measured inorganic Ge concentration of $7.4 \mathrm{pM}$. In spite of their higher abundances, methylated Ge species are unlikely to have co-precipitated with inorganic Ge considering their apparent absence of reactivity in a wide range of biogeochemical processes (Lewis et 
al.,1985), including during early diagenesis leading to inorganic Ge sequestration in Fe-rich marine sediments (King et al., 2000). This situation may be different using other analytical methods involving the generation of volatile Ge hydride directly from seawater (Hambrick et al., 1984). Considering that methylated (i.e. organically-bound) Ge species should have much lighter Ge isotope composition than inorganic Ge species (Li et al., 2009), it is conceivable that the slightly lighter value obtained for the Bay of Brest $\left(\delta^{74 / 70} \mathrm{Ge}=2.4 \%\right.$ ) compared to deep oceanic waters $\left(\delta^{74 / 70} \mathrm{Ge}=3.1 \%\right.$, see below $)$ could reflect a small proportion of methylated species in our measurements. However, the comparison between surface and deep seawater at BATS (Table 1) yielded similar $\delta^{74 / 70}$ Ge values at about $3.0 \pm 0.1 \%$ despite significant concentration differences ( $7 \mathrm{pM}$ to $24 \mathrm{pM})$. Hence, using a simple mass balance consideration, it is unlikely that methylated Ge species have any influence on the measurement of inorganic Ge species. Moreover, Baronas et al. (2017) recently performed a seawater Ge isotopic analyses separating inorganic Ge from methylated Ge using a liquid nitrogen trapping technique and they obtained similar results for deep seawater at BATS.

Finally, it is unlikely that any significant amount of methylated Ge species was converted to inorganic Ge during extended sample storage or exchanged isotopically with the Ge double spike. Lewis et al. (1985) reported that MMGe and DMGe can be converted to inorganic Ge by strong ultraviolet radiation only in freshwater medium, but not in seawater, which confirmed the apparent stability of these compounds during sample storage, even in acidic conditions. Previous studies (Mortlock and Froelich, 1996) have also demonstrated that organogermanium species do not exchange with the inorganic Ge spike under similar analytical conditions and equilibration time than in our study. Consequently, the methylated Ge species are ignored in the present paper and Ge is used to indicate only the inorganic form (predominantly germanic acid).

\subsection{Seawater samples from the Atlantic and Pacific oceans}

Germanium concentrations and isotopic compositions of the surface (GSI) and deep (GDI) seawater samples from the GEOTRACES IC1 BATS Atlantic intercalibration station $\left(31^{\circ} 40^{\prime} \mathrm{N} 64^{\circ} 10^{\prime} \mathrm{W}\right)$ are presented in Table 1. For GS we obtained $\mathrm{Ge}=7 \mathrm{pM}$ and $\delta^{74 / 70} \mathrm{Ge}=$ $3.09 \pm 0.26$ (2SE). For GD we obtained $\mathrm{Ge}=24 \mathrm{pM}$ and $\delta^{74 / 70} \mathrm{Ge}=2.89 \pm 0.26(2 \mathrm{SE})$. By comparison, Froelich et al. (1985a) reported inorganic Ge concentrations of $3.5 \mathrm{pM}$ and 15.6 pM, respectively, in surface $(10 \mathrm{~m})$ and deep (2000 m) seawater of the Sargasso Sea. Hence Ge concentrations are significantly higher than previously reported. It is possible that such 
increase in Ge concentrations in surface seawater is related to the location of the BATS station near Bermuda, which is a region with typically high seasonal dust deposition. This hypothesis is supported by the fact that GSI and GDI have also relatively high $\mathrm{Fe}$ concentrations ( 0.42 and $0.84 \mathrm{nM}$, respectively) compared to open seawater where dust supply is more limited (Boyle et al., 2012; John and Adkins, 2012). For example, Fe concentrations as low as $0.02 \mathrm{nM}$ (20 times less than the present surface sample) have been documented in the eastern Atlantic Ocean (Sarthou et al., 2003). On the other hand, if significant contamination (i.e. analytical bias) contributed to the increase of Ge concentration in surface seawater, the contaminant would need to have the same isotope composition (i.e. $\delta^{74 / 70} \mathrm{Ge} \approx 3.0 \%$ ) as the average seawater value, which is quite unlikely considering that $\mathrm{Ge}$ in crustal materials has much lighter $\delta^{74 / 70} \mathrm{Ge}(\sim 0.7 \%$ o, Rouxel et al., 2006; Escoube et al., 2012) and our single measurement of procedural blank yielding $\delta^{74 / 70} \mathrm{Ge} \sim 1.6 \%$.

Seawater samples from the Pacific Ocean located SW of Hawaii (FeMo Deep station) and nearby Loihi Seamount show remarkable homogeneity in $\delta^{74 / 70} \mathrm{Ge}$ and Ge concentrations (Table 1). A comparison between unfiltered and filtered samples show a difference of less than $2 \%$ in Ge concentrations and less than $0.3 \%$ in $\delta^{74 / 70} \mathrm{Ge}$ values - both being close to the analytical uncertainties. Considering that both filtered and unfiltered samples were stored acidified to $\mathrm{pH} 1.8$ for several months, these results suggest that Ge occurs essentially in the dissolved form at these water depths (i.e. between 959 to $3497 \mathrm{~m}$ ). Considering the entire dataset obtained for the composite samples recovered during cruise Loihi 2014, we obtained average values of $\delta^{74 / 70} \mathrm{Ge}=3.18 \pm 0.32 \%$ o (2SD, $\left.\mathrm{n}=8\right)$ and $\mathrm{Ge}=101 \pm 18 \mathrm{pM}(2 \mathrm{SD}, \mathrm{n}=8)$. These measured Ge concentrations are indistinguishable from previously reported values for the deep Pacific Ocean (Froelich et al., 1985a; Mortlock et al., 1993). Filtered samples from the FeMo Deep station (Table 1) recovered at $500 \mathrm{~m}$ and 4000-4900 m depths yielded $\delta^{74 / 70} \mathrm{Ge}=3.13 \pm 0.11 \%$ and $3.27 \pm 0.06 \%$ respectively, confirming the homogeneity of Ge isotope composition in the deep Pacific Ocean. As expected, the Ge concentration of $86 \mathrm{pM}$ obtained at $500 \mathrm{~m}$ depth is lower than that for deeper water ( $>4000 \mathrm{~m}, \mathrm{Ge} \approx 117 \mathrm{pM}$ ), again consistent with previous studies (Froelich et al., 1985a; Mortlock et al., 1993).

\subsection{Seawater profiles from the Southern Ocean}


Germanium concentrations and isotope compositions at the three stations in the Southern Ocean (Sars, WAP and Burdwood Bank) are reported in Fig. 4, 5 and 6. Germanium and Si concentrations show typical nutrient-type profiles, with lower Ge concentrations (down to $15 \mathrm{pM}$ ) in surface waters, increasing with depth up to $106 \mathrm{pM}$ below $1000 \mathrm{~m}$. Station WAP shows steeper gradients in Ge, Si and other nutrient at mid water depth compared to the other stations (Fig. 5). Using the relationship between $\mathrm{Ge}$ and $\mathrm{Si}$ concentrations (Fig. 7), we obtained an average Ge/Si ratio of $0.775 \pm 0.036(\mu \mathrm{mol} / \mathrm{mol})$ which is consistent within our error to the global oceanic $\mathrm{Ge} / \mathrm{Si}$ ratio of $0.760 \pm 0.004$ $(\mu \mathrm{mol} / \mathrm{mol})$ determined by Sutton et al. (2010). A plot of Ge versus Si concentration produced an intercept of $3.6 \pm 3.3 \mathrm{pM}$, which is higher but also within error of the intercept of $1.27 \pm 0.24 \mathrm{pM}$ reported previously using a much larger dataset (Sutton et al., 2010).

The Ge isotopic profiles at Sars and WAP show distinct features. Firstly, surface waters are characterized by the heaviest $\delta^{74 / 70}$ Ge values at $\sim 3.5$ to $3.7 \%$ o. Secondly, a minimum of $\delta^{74 / 70} \mathrm{Ge}$ is observed at mid-water depths, between 500 and $1000 \mathrm{~m}$. Below 1000 $\mathrm{m}, \delta^{74 / 70} \mathrm{Ge}$ values remain relatively constant at both stations, yielding an average of $3.17 \pm$ $0.19 \% \circ(2 \mathrm{SD}, \mathrm{n}=7)$ and $3.21 \pm 0.21 \% \circ(2 \mathrm{SD}, \mathrm{n}=5)$ for Sars and WAP respectively. Ge isotope compositions at the Burdwood Bank station also fall within a range of $\sim 2.9$ to $3.3 \%$, except for a single sample at $3250 \mathrm{~m}$ that show lighter $\delta^{74 / 70} \mathrm{Ge}$ at $\sim 2.4 \%$ o.

\subsection{Germanium/Silicon and Ge isotope composition of deep sea sponges}

Modern sponges from the Southern Ocean present $\delta^{74 / 70} \mathrm{Ge}$ values ranging from 1.79 to $2.45 \%$ in agreement with previously reported $\delta^{74 / 70} \mathrm{Ge}$ values of Pacific Ocean sponges (Rouxel et al., 2006). The dataset include different species of demosponges (Demospongiae) and glass-sponges (Hexactinellida) sampled at water depths of 600 to $2266 \mathrm{~m}$. As presented in Fig. 8, no systematic relationship between $\delta^{74 / 70} \mathrm{Ge}$ values and other parameters could be identified. In particular, we did not find an inverse linear relationship between sponge $\delta^{7 / / 70} \mathrm{Ge}$ and [Si], which has been previously reported for $\delta^{30} \mathrm{Si}$ and [Si] (Hendry et al., 2010). Compared to overlying seawater, sponges are fractionated toward light Ge isotopes, with a

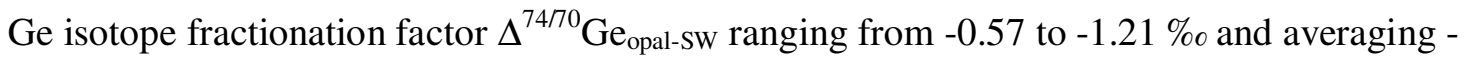
$0.87 \pm 0.37 \%$ o $(2 \mathrm{SD}, \mathrm{n}=12)$. Germanium concentrations ranged from 0.13 to $0.35 \mathrm{ppm}$, corresponding to $\mathrm{Ge} / \mathrm{Si}$ ratios of 0.11 to $0.30 \mu \mathrm{mol} / \mathrm{mol}$, which is much lower than the 
modern seawater $\mathrm{Ge} / \mathrm{Si}$ ratio of $0.7 \mu \mathrm{mol} / \mathrm{mol}$ and consistent with previous studies (Ellwood et al., 2006; Rouxel et al., 2006).

\section{Discussion}

\subsection{Germanium isotope systematics in the Southern Ocean}

The Southern ocean is a complex zone where the mixing of waters from three oceans occurs. The modern day Southern Ocean has large [Si] gradients, with [Si] increasing polewards and with depth due to a combination of water mass mixing, a sloping isopycnal, and opal remineralization (Pollard et al., 2002). The Southern Ocean plays an important role in marine carbon exchange due to high primary productivity and the formation of deep waters with high preformed nutrients (Nelson et al., 1995; Sarmiento et al., 2004). The water masses in the Drake Passage are well known (Orsi et al., 1995; Orsi et al., 1999; Meredith et al., 2011) and include: Antarctic Surface Water (AASW), Antarctic Bottom Water (AABW), Lower Circumpolar Deep Water (LCDW), Upper Circumpolar Deep Water (UCDW) and Antarctic Intermediate Water (AAIW) (Fig. 9). The UCDW is characterized by an oxygen minimum and nutrient maximum, while the LCDW is denser $\left(S_{\max }=34.7\right)$ and penetrates south of the Antarctic Circumpolar Current (ACC) into the subpolar regime underneath the AASW, i.e. below direct surface influence and characterized by a subsurface temperature minimum. The UCDW spreads poleward and often reaches the Antarctic continental shelves.

The WAP station is separated from the Sars and Burdwood Bank stations by the polar front (PF). Burdwood Bank is characterized by an important influence of the AAIW, which provides oxygen to $1000 \mathrm{~m}$ depth, and an oxygen minimum that is pronounced from $1200 \mathrm{~m}$ to $2000 \mathrm{~m}$ (Key et al., 2004). The Sars and WAP off slope stations both have oxygen minima at $800 \mathrm{~m}$ depth. There is an influence of LCDW from $1800 \mathrm{~m}$ to the bottom, which carries oxygen at depth to the Sars station (Key et al., 2004). A comparison between the $\delta^{74 / 70} \mathrm{Ge}$ of dissolved inorganic Ge and oceanographic parameters (e.g. fluorescence, salinitytemperature) at the three stations do not show systematic relationships, suggesting, as a whole, that the different water masses of the Southern Ocean have relatively similar Ge isotope compositions. This contrasts with $\mathrm{Si}$ isotope systematics of the Southern Ocean, which are characterized by distinct $\delta^{30} \mathrm{Si}$ signatures in the different water masses (Fripiat et 
al., 2011). Considering that the residence time of $\mathrm{Ge}$ is probably shorter than that of $\mathrm{Si}$ (between 10,000 to 17,000 years, Treguer and De La Rocha, 2013), heterogeneity in Ge isotope composition between different water masses should be expected.

In detail, there is indeed some distinct Ge isotope variability in the water column profiles. We observed that the lowest $\delta^{74 / 70} \mathrm{Ge}$ values tend to be related to UCDW and LCDW (minimum of 2.62 and $2.44 \%$ respectively) while the heaviest deep water values were observed for the AABW (range of 2.97 to $3.32 \%$ ). The larger variations of $\delta^{74 / 70} \mathrm{Ge}$ at the Sars station are also observed at the interface between AAIW and LCDW. In the Burdwood Bank water column data, significant variations of $\delta^{74 / 70} \mathrm{Ge}$ are also observed at the interface between AAIW and UCDW. For both Sars and WAP profiles, the heaviest $\delta^{74 / 70} \mathrm{Ge}$ values, up to $\sim 3.7 \%$ and $\sim 3.5 \%$, are systematically observed in the shallowest sample (part of AAIW), coinciding with the samples with the highest fluorescence (Table 2). Hence, it can be suggested that the concomitant increase of $\delta^{74 / 70} \mathrm{Ge}$ and depletion of Ge in surface seawater at Sars may be related to phytoplankton biomass, and therefore explained by biological uptake. We note, however, that higher sample resolution may be needed to fully resolve the apparent relationships between $\mathrm{Ge}$ isotope fractionation and the deep chlorophyll maximum for this ocean region. Depth profiles at Sars also show a subsurface maximum of $\mathrm{Ge} / \mathrm{Si}$, which may result from Ge/Si fractionation during Si uptake (Murnane and Stallard, 1988; Froelich et al., 1989; Ellwood and Maher, 2003; Sutton et al., 2010). In Fig. 10, $\delta^{74 / 70} \mathrm{Ge}$ versus Ge concentrations are reported for the stations where surface seawater was sampled (i.e. Sars and WAP). Following the approach previously used for Si isotopes (De La Rocha et al., 1997), we modeled the variations of $\delta^{74 / 70} \mathrm{Ge}$ versus Ge using a Rayleigh distillation model, considering deep values (i.e. $>1000 \mathrm{~m}$ ) of $\mathrm{Ge}=110 \mathrm{pM}$. Model results for the uppermost water $(>1000 \mathrm{~m})$ at the Sars station suggest that surface seawater values can be explained by

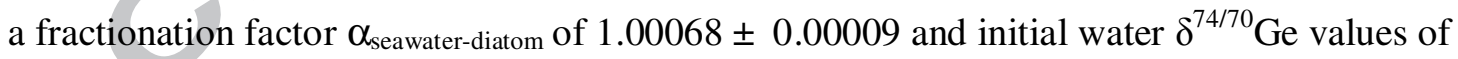
$2.26 \pm 0.11 \%$. This model, however, cannot be extrapolated to deeper waters $(>1300 \mathrm{~m})$, which are characterized by heavier $\delta^{74 / 70} \mathrm{Ge}$ values at $3.1 \%$ (Fig. 10). It is also unlikely that $\mathrm{Si}$ and $\mathrm{Ge}$ in these surface waters were sourced from above $1300 \mathrm{~m}$. Hence, biological removal of Ge in surface waters may not be the sole mechanism explaining the observed water column variations of both Ge concentrations and isotopic compositions at Sars. For the WAP station, the fractionation factor is closer to unity with $\alpha_{\text {seawater-diatom }}$ of $\square \square \square \square \square \square \square \pm$ 0.00011 , with initial water $\delta^{74 / 70} \mathrm{Ge}$ value of $3.1 \pm 0.05 \%$. 
We now further evaluate whether subsurface water mixing could, instead, explain most of the variability observed in Sars and other stations. In particular, the minimum $\delta^{74 / 70} \mathrm{Ge} \approx 2.6 \%$ at Sars may suggest the presence of isotopically lighter water masses located at the interface between AAIW and LCDW. Klunder et al. (2014) observed an input of dissolved iron (DFe) from the shelves around Elephant Island into the Drake Passage, which is consistent with earlier findings (Dulaiova et al., 2009). Hence, we propose that similar shelf input may, in principle, contribute to lower $\delta^{74 / 70} \mathrm{Ge}$ values, shifting deeper water (500-1000 m depth) from typical deepwater $\delta^{74 / 70} \mathrm{Ge}$ values of $3.1 \%$ toward more crustal values at around $0.7 \%$ o. However, since DFe concentrations were not measured in the same samples as our new Ge data, it is difficult to further test this hypothesis. Considering the different reactivity and residence time of $\mathrm{Fe}$ and $\mathrm{Ge}$, it is also possible that the same water column anomaly may not be observed for both elements in a similar manner. Higher resolution sampling, together with measurements of other important nutrients such as $\mathrm{PO}_{4}$ and Fe, should ultimately allow us to determine the relative importance of the two mechanisms, driven by differential depth regeneration and/or shelf input, for Ge isotope variations in water column profiles.

Far-field hydrothermal venting from the South East Pacific Rise (Well et al., 2003), the Bransfield Strait (Klinkhammer et al., 2001) and the East Scotia Ridge back-arc basin (James et al., 2014) may also potentially impact Ge geochemistry in the region. However, the $\approx 0.5 \%$ o shift observed for $\delta^{74 / 70} \mathrm{Ge}$ values at $3251 \mathrm{~m}$ depth at the Burdwood Bank station is unlikely to result from the contribution of isotopically light hydrothermally-derived Ge (Escoube et al., 2015). In particular, any significant hydrothermal contribution would have been reflected in elevated ${ }^{3} \mathrm{He}$ concentrations which was not observed in this region (Sudre et al., 2011) or an increase in Ge/Si ratios at the same depth which was not observed either (Table 2).

\subsection{Potential mechanisms of Ge isotope fractionation by siliceous phytoplankton}

Our water column concentration and isotopic composition profiles exhibit distinct trends towards lower [Ge] and heavier $\delta^{74 / 70}$ Ge values at shallower depths (Fig. 4-6, 10), indicating that it is possible that Ge isotopes are fractionated during phytoplankton uptake by $0.3 \%$ o to $0.6 \%$ o. Such biological fractionation could arise as a result of Ge uptake and incorporation into diatom opal, or as a result of incorporation of Ge into organic matter 
within phytoplankton cells. We explore here the potential mechanisms leading to, or inversely muting, $\mathrm{Ge} / \mathrm{Si}$ and $\mathrm{Ge}$ isotope fractionations by phytoplankton.

In a reconnaissance study, Mantoura (2006) reported the experimental determination of Ge isotope fractionation during biological uptake by two marine diatoms, Skeletonema costatum and Thalassiosira weissflogii. Neither of these species appeared to fractionate Ge isotopes during biomineralization of opal. These results were obtained across a wide range of $\mathrm{Ge} / \mathrm{Si}$ in the culture media. There was no change in measured $\delta^{74 / 70} \mathrm{Ge}$ values of opal within the analytical precision of $0.3 \%$, even for Si depletion in solution up to $25 \%$. Since experiments were not run at higher percentages of Si uptake, it remains unclear as to whether Rayleigh-type fractionation behavior could lead to resolvable seawater $\delta^{74 / 70} \mathrm{Ge}$ variations. These diatom species are also not representative of the dominant sub-polar taxa in the Southern Ocean (Crosta et al., 2005) and we cannot rule out potential species-dependent Ge isotope fractionation by marine diatoms as previously reported for $\mathrm{Si}$ isotopes (Sutton et al., 2013). An important result, however, is that Ge isotope composition measured in uncleaned diatoms, i.e. whole diatom including organic matter and opal, yielded a fractionation factor $\alpha_{\text {seawater-diatom }}=1.001 \pm 0.0004(2 \mathrm{SD})$ (Mantoura, 2006). Hence, considering the strong affinity of Ge for organic matter, Ge sequestration in phytoplankton cellular material during biological uptake may provide a pool of isotopically light Ge that could be decoupled from $\mathrm{Ge}$ in opal at depth during remineralization, resulting in heavier $\delta^{74 / 70} \mathrm{Ge}$ values in surface waters (up to $\sim 3.7 \%$ ). Evidence that Ge isotope distributions may be driven by organic matter remineralization is provided by our water column depth profiles, which show a correspondence between apparent oxygen utilization (AOU) - a measure of cellular material degradation - and seawater $\delta^{74 / 70} \mathrm{Ge}$ (Fig. 4 - 6). For example, a local minimum in $\delta^{74 / 70} \mathrm{Ge}$ is observed at the same depth as the AOU maximum at $\sim 800 \mathrm{~m}$ at Sars (Fig. 4) with $\delta^{74 / 70} \mathrm{Ge}$ values as low as $\sim 2.6 \%$, which is likely the result of the release of light Ge isotopes during the remineralization of settling organic matter. The same relationships were however not observed at WAP off slope (Fig. 5) and Burdwood Bank (Fig. 6). Considering that seawater samples at the three Southern Ocean stations were recovered during the austral fall 2011, when sea surface temperatures were already low $\left(2.81\right.$ and $-0.15^{\circ} \mathrm{C}$, at stations Sars and WAP, respectively), the concept of AOU should be used with caution. In particular, it has been shown that $\mathrm{O}_{2}$ concentration can be significantly depleted under the ice due to incomplete equilibration with atmosphere (Gordon et al., 1984), providing a possible 
explanation for the lack of relationships between $\delta^{74 / 70}$ Ge and AOU at WAP off slope and Burdwood Bank.

\subsection{Germanium isotope fractionation by sponges}

In a preliminary study, Rouxel et al. (2006) reported heavy Ge isotope compositions relative to bulk oceanic-continental crust for opal sponge spicules obtained from live specimens growing on the seafloor in North East Pacific, with $\delta^{74 / 70} \mathrm{Ge}$ values ranging from 1.56 to $2.60 \%$ (recalculated relative to NIST 3120a). The new Ge isotope analysis of sponges from the Southern Ocean showed a similar, albeit smaller range from 1.79 to $2.45 \%$. Combining these results with $\delta^{74 / 70} \mathrm{Ge}$ values of overlying seawater, we determined a Ge isotope fractionation factor $\Delta^{74 / 70} \mathrm{Ge}_{\text {opal-Sw }}$ of $-0.87 \pm 0.37 \%$ (2SD, $\left.\mathrm{n}=12\right)$ during Ge uptake by sponges. Although no clear relationships could be derived between $\delta^{74 / 70} \mathrm{Ge}$, water depth and oceanographic parameters (e.g. nutrient, temperature-salinity and AOU) or sponge species, these results confirm earlier assumptions that sponges fractionate Ge isotopes during biomineralization, and discriminate against heavy $\mathrm{Ge}$ isotopes, as already observed for $\mathrm{Si}$ isotopes (De La Rocha, 2003; Hendry and Robinson, 2012).

Sponges are considered to have a low affinity for silicic acid (Reincke and Barthel, 1997) and the inefficient silicon uptake mechanism has been suggested to explain their preferential enrichment in light Si isotopes (De La Rocha, 2003). More recently, Hendry et al. (2010) determined $\delta^{30} \mathrm{Si}$ values of modern deep-sea sponge spicules and showed that they vary with ambient seawater Si concentrations. The fractionation factor $\Delta^{30} \mathrm{Si}_{\text {opal-sw }}$ ranged from ca. -2.5 to $-5.5 \%$ and showed a positive relationship with $\mathrm{Si}$, which has been attributed to growth rate effects (Wille et al., 2010; Hendry and Robinson, 2012). However, no

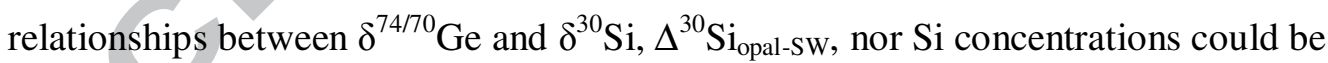
identified (Fig. 8), suggesting a significant decoupling between Ge and Si isotopes during sponge biomineralization.

Biosilicification in sponges is controlled by two enzymes: silicatein, which promotes condensation reactions, and silicase, which dissolves silica (Muller et al., 2007). Although it is still unclear which pathways or reactions during the biosilicification process result in $\mathrm{Si}$ isotopic fractionation, our results show that Ge incorporation in sponges likely proceeds via a different pathways than Si. The non-linear relationship between Si isotope fractionation and silicon concentration has been modeled assuming that the fractionation occurs in several 
steps: firstly as the $\mathrm{Si}$ is transported into the cell, secondly as the $\mathrm{Si}$ is polymerized, and thirdly as Si is lost from the cell (Wille et al., 2010; Hendry and Robinson, 2012). This model indicates that $\mathrm{Si}$ isotope fractionation associated with uptake transport is constant whereas fractionation during spicule formation increases as a function of external Si concentration. Using this model, we propose that the lack of correlation between $\Delta^{74 / 70} \mathrm{Ge}_{\text {opal-sw }}$ and $\Delta^{30} \mathrm{Si}_{\text {opal-Sw }}$ may suggest that Ge isotopes are fractionated solely during the uptake step (i.e. which is also associated with constant $\mathrm{Si}$ isotope fractionation). Silicification of large spicules occurs extracellularly in association with an organic matrix and is controlled by protein interactions (Schröder et al., 2008). It is therefore likely that the apparent $\Delta^{74 / 70} \mathrm{Ge}_{\text {opal-sw }}$ of $0.87 \%$ result from the interaction of $\mathrm{Ge}(\mathrm{OH})_{4}$ with organic compounds, possibly through the formation of 6-coordinated Ge bearing organic complexes which may be enriched in light isotopes by up to $4 \%$ at $25{ }^{\circ} \mathrm{C}$ relative to $\mathrm{Ge}(\mathrm{OH})_{4}$ ( $\mathrm{Li}$ et al., 2009).

Measurements of Ge/Si ratios in sponge opal range from 0.11 to $0.30(\mu \mathrm{mol} / \mathrm{mol})$, which is significantly lower than the seawater Ge/Si ratio of $0.76 \mu \mathrm{mol} / \mathrm{mol}$. In a previous study, Ellwood et al. (2006) reported an even larger range of $\mathrm{Ge} / \mathrm{Si}$ ratios, between about 0.075 to $0.380 \mu \mathrm{mol} / \mathrm{mol}$, in sponge opal collected from a range of depths and locations. A correlation between $\mathrm{Ge} / \mathrm{Si}_{\mathrm{sp}}$ in sponge opal and $\mathrm{Ge}$ concentration in seawater was also reported, suggesting that either $\mathrm{Ge} / \mathrm{Si}_{\mathrm{sp}}$ is solely dependent on the $\mathrm{Ge}$ concentration of the surrounding seawater and is independent of the Si concentration of that seawater, or that $\mathrm{Ge} / \mathrm{Si}_{\mathrm{sp}}$ is the product of strong $\mathrm{Ge} / \mathrm{Si}$ fractionation during both $\mathrm{Ge}$ and $\mathrm{Si}$ uptake from the seawater surrounding the sponge (Ellwood et al., 2006). Our results are broadly consistent, but further suggest that $\mathrm{Ge} / \mathrm{Si}_{\mathrm{sp}}$ is not solely a function of Ge concentration in seawater, since several samples deviate from the relationship reported by Ellwood et al. (2006) (Fig. 8). While $\mathrm{Ge} / \mathrm{Si}$ and $\mathrm{Ge}$ isotope ratios in sponge opal do not appear to be species dependent (Fig. 8), sponges from the same area and the same species (e.g. sample DR13-47 and DR16-47) yielded contrasting $\delta^{74 / 70} \mathrm{Ge}$ and $\mathrm{Ge} / \mathrm{Si}$ values, suggesting that vital effects between or within species may be significant in controlling both Ge isotope fractionation and $\mathrm{Ge} / \mathrm{Si}$ ratios.

Although additional work is required, it seems likely that the same mechanisms leading to the discrimination of Ge against Si during biomineralization are also responsible for the fractionation of Ge isotopes. This hypothesis is supported by the fact that diatoms, which are known to produce subtle $\mathrm{Ge} / \mathrm{Si}$ fractionation in surface waters (Sutton et al., 2010), also generate very limited Ge isotope fractionation. In contrast, marine sponges, which are characterized by Ge/Si values considerably lower than seawater, showed the largest Ge 
isotope fractionation factors. This general model is also consistent with $\mathrm{Si}$ isotope systematics, i.e. sponges show larger degree of $\mathrm{Si}$ isotope fractionation than diatoms (De La Rocha et al., 1997; Wille et al., 2010).

\subsection{A preliminary estimate of Ge isotope composition of seawater and implications for the} global Ge budget

Results for the deep Pacific Ocean off Hawaii and deep Atlantic off Bermuda (BATS station) $>1000 \mathrm{~m}$ water depths show nearly identical $\delta^{74 / 70} \mathrm{Ge}$ of $3.19 \pm 0.31 \%$ (2SD, $\left.\mathrm{n}=9\right)$ and $2.93 \pm 0.10 \%$ o (2SD, $\mathrm{n}=2)$. Vertical distributions of Ge concentrations and isotope compositions in the Southern Ocean for water depths $>1300 \mathrm{~m}$ yielded an average $\delta^{74 / 70} \mathrm{Ge}$ value of $3.13 \pm 0.25 \%$ o (2SD, $n=14)$. These observations suggest that Ge isotope composition is relatively homogeneous in deep seawater and is not modified significantly through global thermohaline circulation and the biogenic uptake of dissolved silica. Hence, even with this relatively limited dataset, it is possible to determine a global deep seawater composition of approximately $\delta^{7 / 70} \mathrm{Ge}=3.14 \pm 0.38 \%$ o (2SD, $\left.\mathrm{n}=27\right)$.

Mantoura (2006) investigated the Ge/Si and $\delta^{74 / 70} \mathrm{Ge}$ records of diatom opal from Late Quaternary sediments and found no difference between average glacial and average interglacial $\delta^{74 / 70} \mathrm{Ge}$ opal values. The average $\delta^{74 / 70} \mathrm{Ge}_{\text {opal }}$ value over the period 68 to $178 \mathrm{ka}$ (S. Atlantic, ODP site 1094) was determined to be $3.35 \pm 0.29 \%$ o (2SD, $n=29)$. Given that potential glacial-interglacial changes in $\delta^{74 / 70} \mathrm{Ge}_{\mathrm{opal}}$ are barely outside the analytical error, despite large changes in growth conditions, these initial results are fully consistent with our finding that diatom opal does not fractionate significantly Ge isotopes nor Ge/Si and thus might provide a potential paleoceanographic archive of secular Ge isotope variations in seawater.

Overall, our study supports the hypothesis that sedimentary diatomaceous sediments are potentially good archives for marine Ge biogeochemical cycling in the past. This new paleoceanographic tool could be applied to understand changes in hydrothermal versus continental Ge sources or Ge sinks over the past, considering the contrasting Ge isotope composition of hydrothermal vent fluids and $\mathrm{Ge}$ sinks related to Ge sequestration in Fe-rich sediments (see Escoube et al., 2015). The use of Ge isotopes seems also particularly relevant as a complementary tool for $\mathrm{Si}$ isotopes, especially if different water masses carry their own 
$\delta^{74 / 70} \mathrm{Ge}$ signatures that are decoupled from their $\delta^{30} \mathrm{Si}$ compositions. In this case, Ge isotopes could provide additional information about the source of the water mass (and its potential interaction with shelf environments), while Si isotopes would add additional information on the operation of the biological pump. Surface seawater conditions are recorded in diatoms, meaning that diatomaceous opal $\delta^{74 / 70} \mathrm{Ge}$ may trace nutrient sources (e.g. shelf input) and their effect on primary productivity, while sponges provide information on deeper water (e.g. hydrothermal input) and long-term oceanic circulation. Additional study of Ge isotope systematics in coastal waters and rivers is now required to address the importance of continental run-off and silicate weathering, as well as anthropogenic input (e.g. coal combustion), in the marine biogeochemical cycling of Ge.

\section{Conclusion}

Prior to this study and the recent study of Baronas et al. (2017), our knowledge of Ge isotope systematics in seawater was limited by the analytical difficulties to precisely measure Ge isotope composition in sub-nanomolar amounts of Ge in seawater. Our newly developed method offers the following advantages 1) utilization of a double-spike which permits correction of potential Ge isotope mass fractionation in the case of incomplete recovery, 2) sufficient sensitivity using hydride-generation system to measure Ge in seawater at very low concentrations (e.g. surface waters), 3) a preconcentration technique using co-precipitation with Fe-oxyhydroxides which can be set up on a research cruise, allowing the rapid separation of Ge from large volumes of seawater. Additional developments are still required to consistently achieve quantitative recovery (i.e. $100 \%$ yield) of Ge from large seawater volume. Potential blank contamination should also be kept at the minimum (i.e. below 1pM equivalent) in order to improve the measurement of the most analytically challenging surface seawater, especially from nutrient-depleted regions where significant $\mathrm{Ge} / \mathrm{Si}$ fractionation is expected. In this case, Ge isotope systematics may provide an important new proxy to investigate nutrient limitation for biological productivity and their sources in surface seawater, both of which resulting in contrasting trends in $\delta^{30} \mathrm{Si}$ and $\mathrm{Ge} / \mathrm{Si}$ ratios.

The first survey of Ge isotope systematics in seawater from the Pacific, Atlantic and Southern Oceans indicates:

[1] Deep sea waters $(<1000 \mathrm{~m})$ are relatively homogeneous for the three Oceans with a $\delta^{74 / 70} \mathrm{Ge}$ of $3.14 \pm 0.38 \%$ ( $\left.2 \mathrm{SD}, \mathrm{n}=27\right)$. This value is consistent with previous estimates of 
$\delta^{74 / 70} \mathrm{Ge}$ values of seawater using biogenic opal (Mantoura, 2006; Escoube et al., 2015) and recently reported by Baronas et al., (2017).

[2] $\delta^{74 / 70} \mathrm{Ge}$ profiles in the Southern Ocean show significant enrichment in heavy isotopes in surface waters, while a minimum in $\delta^{74 / 70} \mathrm{Ge}$ is observed at the depth of maximum remineralization. A combination of two different mechanisms can explain these profiles. The first process may be driven by biology, namely the fractionation of Ge isotopes by siliceous

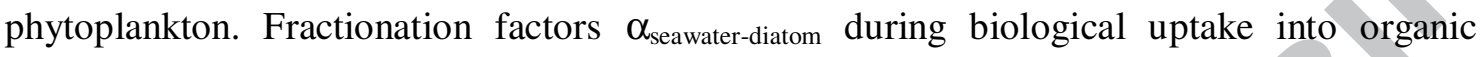
matter were calculated with a Rayleigh distillation model that leads to values of 1.0007 (Sars) and 1.0003 (WAP). Due to the strong affinity of Ge for organic matter, it is expected that the light $\mathrm{Ge}$ isotopes may be incorporated in the soft tissues, leading to isotopically heavier surface seawater compared to deeper seawater. Conversely, the remineralization of the settling particles may be responsible for a decrease of $\delta^{74 / 70} \mathrm{Ge}$ values with depth corresponding to AOU maximum. The second process is driven by physical mixing of water masses. Although $\delta^{74 / 70} \mathrm{Ge}$ values are more homogeneous than $\delta^{30} \mathrm{Si}$ between water masses, significant variations can still be attributed to water masses having contrasting Ge isotope signatures. Deep water masses forming close to the shelf are potentially lighter due to an input of isotopically light lithogenic Ge. Because of the relatively limited number of sampling depths and stations considered in this study, a distinction between these different mechanisms remains difficult at this point. Future study should therefore be aimed at testing the relative importance of internal cycling and source effects in controlling Ge isotope compositions in seawater.

[3] The $\delta^{74 / 70} \mathrm{Ge}$ of sponges and co-located seawater allowed us to determine a Ge isotope fractionation factor of $-0.87 \pm 0.37 \%$ o $(2 \mathrm{SD}, \mathrm{n}=12)$ during Ge uptake by sponges. Hence, similarly to $\mathrm{Si}$ isotopes, sponges discriminate against heavy $\mathrm{Ge}$ isotopes during biomineralization, suggesting that Ge isotopes could serve as an interesting biogeochemical tracer when used in conjunction with $\mathrm{Ge} / \mathrm{Si}$ and $\mathrm{Si}$ isotope systematics. In particular, the apparent lack of correlation between $\mathrm{Ge}$ isotope compositions and $\mathrm{Si}$ (or $\mathrm{Ge}$ ) concentrations contrasts strongly with $\mathrm{Si}$ isotopes, allowing to use coupled $\delta^{74 / 70} \mathrm{Ge}$ and $\delta^{30} \mathrm{Si}$ signatures in sponges to reconstruct a paleoceanographic record of both silicic acid supply and utilization $\left(\delta^{30} \mathrm{Si}\right.$ based proxy) and sources ( $\delta^{74 / 70} \mathrm{Ge}$ based proxy) in seawater.

Finally, the apparent lack of Ge isotope and Ge/Si fractionation during diatom growth remains an area of open research, given that significant fractionation is expected by analogy with the widely investigated Si isotope systematics (De La Rocha et al., 1997; Sutton et al., 
2013). Since the extent of potential biological Ge isotope fractionation in surface seawater is strongly model dependent, combined field studies at higher resolution profile and experimental studies under conditions relevant to the ocean are now required to better understand the biological imprint on the global Ge cycle. 


\section{Acknowledgements:}

Support for Rouxel was provided by LabexMer ANR-10-LABX-19-01, Europole Mer and FP7 (\#247837) grants. International mobility was provided to Guillermic by the LabexMer ANR-10-LABX-19-01 and the Royal Society (Hendry grant \#UF120084). Jill Sutton is thanked for her advice. Emmanuel Ponzevera (IFREMER) and Yoan Germain (IFREMER) are thanked for their technical support, and Rosalind Rickaby (Univ. Oxford) is thanked for the generous use of laboratory space. Brian Glazer, Gabrielle Weiss, Angelos Hannides, Kristen Fogaren (Univ. Hawaii), and Isabelle Baconnais (Univ. Brest) are thanked for their support during cruise FK140626 aboard R/V Falkor. Southern Ocean water and sponge sample collection was funded by the National Science Foundation (OPP ANT grants \#0944474 and \#0902957; PIs Robinson and Waller). Samples from Loihi Seamount were collected as part of a project supported by the Schmidt Ocean Institute. We thank the crews of the R/V Nathaniel B. Palmer, R/V Kilo Moana, and R/V Falkor for assistance with deployments and sample collection during the cruises. We thank Jotautas Baronas, Michael Ellwood, AE Silke Severmann and one anonymous reviewer for their constructive reviews that improved the quality of this paper. 


\section{References}

Baronas, J.J., Hammond, D.E., Berelson, W.M., McManus, J. and Severmann, S. (2016) Germanium-silicon fractionation in a river-influenced continental margin: The Northern Gulf of Mexico. Geochim. Cosmochim. Acta 178, 124-142.

Baronas, J.J., Hammond, D.E., McManus, J., Wheat, C.G. and Siebert, C. (2017) A Global Ge Isotopic Budget. Geochim. Cosmochim. Acta 203, 265-283.

Belissont, R., Boiron, M.C., Luais, B. and Cathelineau, M. (2014) LA-ICP-MS analyses of minor and trace elements and bulk Ge isotopes in zoned Ge-rich sphalerites from the Noailhac - Saint-Salvy deposit (France): Insights into incorporation mechanisms and ore deposition processes. Geochim. Cosmochim. Acta 126, 518-540.

Bennett, S.A., Hansman, R.L., Sessions, A.L., Nakamura, K. and Edwards, K.J. (2011) Tracing iron-fueled microbial carbon production within the hydrothermal plume at the Loihi seamount. Geochim. Cosmochim. Acta 75, 5526-5539.

Boyle, E.A., John, S., Abouchami, W., Adkins, J.F., Echegoyen-Sanz, Y., Ellwood, M., Flegal, A.R., Fornace, K., Gallon, C., Galer, S., Gault-Ringold, M., Lacan, F., Radic, A., Rehkämper, M., Rouxel, O., Sohrin, Y., Stirling, C., Thompson, C., Vance, D., Xue, Z.C. and Zhao, Y. (2012) GEOTRACES IC1 (BATS) contamination-prone trace element isotopes Cd, $\mathrm{Fe}, \mathrm{Pb}, \mathrm{Zn}, \mathrm{Cu}$, and Mo intercalibration. Limnol Oceanogr-Meth 10, 653-665.

Cao, Z.M., Frank, M. and Dai, M.H. (2015) Dissolved silicon isotopic compositions in the East China Sea: Water mass mixing vs. biological fractionation. Limnol. Oceanogr. 60, 16191633.

Crosta, X., Romero, O., Armand, L.K. and Pichon, J.J. (2005) The biogeography of major diatom taxa in Southern Ocean sediments: 2. Open ocean related species. Palaeogeography Palaeoclimatology Palaeoecology 223, 66-92.

De La Rocha, C., Brzezinski, M.A. and De Niro, M.J. (1997) Fractionation of silicon isotopes by marine diatoms during biogenic silica formation. Geochim. Cosmochim. Acta 61, 50515056.

De La Rocha, C. (2003) Silicon isotope fractionation by marine sponges and the reconstruction of the silicon isotope composition of ancient deep water. Geology 31, 423-426.

de Souza, G.F., Slater, R.D., Dunne, J.P. and Sarmiento, J.L. (2014) Deconvolving the controls on the deep ocean's silicon stable isotope distribution. Earth. Planet. Sci. Lett. 398, $66-76$

Dulaiova, H., Ardelan, M.V., Henderson, P.B. and Charette, M.A. (2009) Shelf-derived iron inputs drive biological productivity in the southern Drake Passage. Global Biogeochem. Cycles 23.

Edwards, K.J., Glazer, B.T., Rouxel, O.J., Bach, W., Emerson, D., Davis, R.E., Toner, B.M., Chan, C.S., Tebo, B.M., Staudigel, H. and Moyer, C.L. (2011) Ultra-diffuse hydrothermal venting supports Fe-oxidizing bacteria and massive umber deposition at $5000 \mathrm{~m}$ off Hawaii. Isme Journal 5, 1748-1758. 
Ellwood, M.J. and Maher, W.A. (2003) Germanium cycling in the waters across a frontal zone: the Chatham Rise, New Zealand. Mar. Chem. 80, 145-159.

Ellwood, M.J., Kelly, M., Maher, W.A. and De Deckker, P. (2006) Germanium incorporation into sponge spicules: Development of a proxy for reconstructing inorganic germanium and silicon concentrations in seawater. Earth. Planet. Sci. Lett. 243, 749-759.

Escoube, R., Rouxel, O.J., Luais, B., Ponzevera, E. and Donard, O.F.X. (2012) An Intercomparison Study of the Germanium Isotope Composition of Geological Reference Materials. Geostand. Geoanal. Res. 36, 149-159.

Escoube, R., Rouxel, O., Edwards, K., Glazer, B. and Donard, O. (2015) Coupled Ge/Si and Ge isotope ratios as geochemical tracers of seafloor hydrothermal systems: case studies at Loihi Seamount and East Pacific Rise 950'N. Geochim. Cosmochim. Acta 167, 93-112.

Fripiat, F., Cavagna, A.J., Dehairs, F., Speich, S., Andre, L. and Cardinal, D. (2011) Silicon pool dynamics and biogenic silica export in the Southern Ocean inferred from Si-isotopes. Ocean Sci. 7, 533-547.

Froelich, P.N. and Andreae, M.O. (1981) The marine geochemistry of germanium Ekasilicon. Science 213, 205-207.

Froelich, P.N., Hambrick, G.A., Andreae, M.O., Mortlock, R.A. and Edmond, J.M. (1985a) The geochemistry of inorganic germanium in natural waters. Journal of Geophysical Research-Oceans 90, 1133-1141.

Froelich, P.N., Hambrick, G.A., Kaul, L.W., Byrd, J.T. and Lecointe, O. (1985b)

Geochemical behavior of inorganic germanium in an unperturbed estuary. Geochim. Cosmochim. Acta 49, 519-524.

Froelich, P.N., Mortlock, R.A. and Shemesh, A. (1989) Inorganic germanium and silica in the Indian Ocean: Biological fractionation during $(\mathrm{Ge} / \mathrm{Si})$ OPAL formation. Global Biogeochem. Cycles, 3, 79-88.

Gordon, A.L., Chen, C.T.A. and Metcalf, W.G. (1984) Winter mixed layer entrainment of Weddell Deep Water. Journal of Geophysical Research-Oceans 89, 637-640.

Grasse, P., Ehlert, C. and Frank, M. (2013) The influence of water mass mixing on the dissolved Si isotope composition in the Eastern Equatorial Pacific. Earth. Planet. Sci. Lett. 380, 60-71.

Hambrick, G.A., Froelich, P.N., Andreae, M.O. and Lewis, B.L. (1984) Determination of methylgermanium species in natural waters by graphite furnace atomic absorption spectrometry with hydride generation. Anal Chem 56, 421-424.

Hammond, D.E., McManus, J., Berelson, W.M., Meredith, C., Klinkhammer, G.P. and Coale, K.H. (2000) Diagenetic fractionation of Ge and Si in reducing sediments: The missing Ge sink and a possible mechanism to cause glacial/interglacial variations in oceanic $\mathrm{Ge} / \mathrm{Si}$. Geochim. Cosmochim. Acta 64, 2453-2465. 
Hendry, K.R., Georg, R.B., Rickaby, R.E.M., Robinson, L.F. and Halliday, A.N. (2010) Deep ocean nutrients during the Last Glacial Maximum deduced from sponge silicon isotopic compositions. Earth. Planet. Sci. Lett. 292, 290-300.

Hendry, K.R. and Robinson, L.F. (2012) The relationship between silicon isotope fractionation in sponges and silicic acid concentration: Modern and core-top studies of biogenic opal. Geochim. Cosmochim. Acta 81, 1-12.

Hendry, K.R. and Andersen, M.B. (2013) The zinc isotopic composition of siliceous marine sponges: Investigating nature's sediment traps. Chem. Geol. 354, 33-41.

James, R.H., Green, D.R.H., Stock, M.J., Alker, B.J., Banerjee, N.R., Cole, C., German, C.R., Huvenne, V.A.I., Powell, A.M. and Connelly, D.P. (2014) Composition of hydrothermal fluids and mineralogy of associated chimney material on the East Scotia Ridge back-arc spreading centre. Geochim. Cosmochim. Acta 139, 47-71.

John, S.G. and Adkins, J. (2012) The vertical distribution of iron stable isotopes in the North Atlantic near Bermuda. Global Biogeochem. Cycles 26.

Kaya, M. and Volkan, M. (2011) Germanium determination by flame atomic absorption spectrometry: An increased vapor pressure-chloride generation system. Talanta 84, 122-126.

King, S.L., Froelich, P.N. and Jahnke, R.A. (2000) Early diagenesis of germanium in sediments of the Antartic South Atlantic: In search of the missing Ge sink. Geochim. Cosmochim. Acta 64, 1375-1390.

Klinkhammer, G.P., Chin, C.S., Keller, R.A., Dahlmann, A., Sahling, H., Sarthou, G., Petersen, S. and Smith, F. (2001) Discovery of new hydrothermal vent sites in Bransfield Strait, Antarctica. Earth. Planet. Sci. Lett. 193, 395-407.

Klunder, M.B., Laan, P., De Baar, H.J.W., Middag, R., Neven, I. and Van Ooijen, J. (2014) Dissolved Fe across the Weddell Sea and Drake Passage: impact of DFe on nutrient uptake. Biogeosciences 11, 651-669.

Kurtz, A.C., Derry, L.A. and Chadwick, O.A. (2002) Germanium-silicon fractionation in the weathering environment. Geochim. Cosmochim. Acta 66, 1525-1537.

Kurtz, A.C., Lugolobi, F. and Salvucci, G. (2011) Germanium-silicon as a flow path tracer: Application to the Rio Icacos watershed. Water Resour. Res. 47.

Lewis, B.L., Froelich, P.N. and Andreae, M.O. (1985) Methylgermanium in natural waters. Nature 313, 303-305.

Lewis, B.L., Andreae, M.O. and Froelich, P.N. (1989) Sources and sinks of methylgermanium in natural waters. Mar. Chem. 27, 179-200.

Li, X.F., Zhao, H., Tang, M. and Liu, Y. (2009) Theoretical prediction for several important equilibrium Ge isotope fractionation factors and geological implications. Earth. Planet. Sci. Lett. 287, 1-11.

Luais, B. (2012) Germanium chemistry and MC-ICPMS isotopic measurements of Fe-Ni, Zn alloys and silicate matrices: Insights into deep Earth processes. Chem. Geol. 334, 295-311. 
Mantoura, S. (2006) Development and Application of Opal Based Paleoceanographic Proxies, Univ. Cambridge. University of Cambridge, Cambridge, p. 218.

Martinez, C.E. and McBride, M.B. (1998) Coprecipitates of $\mathrm{Cd}, \mathrm{Cu}, \mathrm{Pb}$ and $\mathrm{Zn}$ in iron oxides: Solid phase transformation and metal solubility after aging and thermal treatment. Clays Clay Miner. 46, 537-545.

McManus, J., Hammond, D.E., Cummins, K., Klinkhammer, G.P. and Berelson, W.M. (2003) Diagenetic Ge-Si fractionation in continental margin environments: Further evidence for a nonopal sink. Geochim. Cosmochim. Acta 67, 4545-4557.

Meredith, M.P., Woodworth, P.L., Chereskin, T.K., Marshall, D.P., Allison, L.C., Bigg, G.R., Donohue, K., Heywood, K.J., Hughes, C.W., Hibbert, A., Hogg, A.M., Johnson, H.L., Jullion, L., King, B.A., Leach, H., Lenn, Y.D., Maqueda, M.A.M., Munday, D.R., Garabato, A.C.N., Provost, C., Sallee, J.B. and Sprintall, J. (2011) Sustained monitoring of the Southern Ocean at Drake Passage: Past achievements and future priorities. Rev. Geophys. 49.

Mortlock, R.A. and Froelich, P.N. (1987) Continental weathering of germanium: Ge/Si in the global discharge. Geochim. Cosmochim. Acta 51, 2075-2082.

Mortlock, R.A., Froelich, P.N., Feely, R.A., Massoth, G.J., Butterfield, D.A. and Lupton, J.E. (1993) Silica and germanium in Pacific Ocean hydrothermal vents and plumes. Earth. Planet. Sci. Lett. 119, 365-378.

Muller, W.E.G., Li, J.H., Schroder, H.C., Qiao, L. and Wang, X.H. (2007) The unique skeleton of siliceous sponges (Porifera; Hexactinellida and Demospongiae) that evolved first from the Urmetazoa during the Proterozoic: a review. Biogeosciences 4, 219-232.

Murnane, R.J. and Stallard, R.F. (1988) Germanium/silicon fractionation during biogenic opal formation. Paleoceanography 3, 461-469.

Nelson, D.M., Treguer, P., Brzezinski, M.A., Leynaert, A. and Queguiner, B. (1995) Production and dissolution of biogenic silica in the ocean: Revised global estimates, comparison with regional data and relationship to biogenic sedimentation. Global Biogeochem. Cycles 9, 359-372.

Olbers, D., Gouretski, V.V., Seiß, G., Schröter, J., 1992. Southern Ocean Atlas (ODV).

Orsi, A.H., Whitworth, T. and Nowlin, W.D. (1995) On the meridional extent and fronts of the Antarctic Circumpolar Current. Deep-Sea Research Part I-Oceanographic Research Papers 42, 641-673.

Orsi, A.H., Johnson, G.C. and Bullister, J.L. (1999) Circulation, mixing, and production of Antarctic Bottom Water. Prog. Oceanogr. 43, 55-109.

Pokrovski, G.S. and Schott, J. (1998) Experimental study of the complexation of silicon and germanium with aqueous organic species: Implications for germanium and silicon transport and $\mathrm{Ge} / \mathrm{Si}$ ratio in natural waters. Geochim. Cosmochim. Acta 62, 3413-3428.

Pokrovsky, O.S., Pokrovski, G.S., Schott, J. and Galy, A. (2006) Experimental study of germanium adsorption on goethite and germanium coprecipitation with iron hydroxide: $\mathrm{X}$-ray 
absorption fine structure and macroscopic characterization. Geochim. Cosmochim. Acta 70, $3325-3341$.

Pollard, R.T., Lucas, M.I. and Read, J.F. (2002) Physical controls on biogeochemical zonation in the Southern Ocean. Deep-Sea Research II 49, 3289-3305.

Qi, H.W., Rouxel, O., Hu, R.Z., Bi, X.W. and Wen, H.J. (2011) Germanium isotopic systematics in Ge-rich coal from the Lincang Ge deposit, Yunnan, Southwestern China. Chem. Geol. 286, 252-265.

Raven, K.P., Jain, A. and Loeppert, R.H. (1998) Arsenite and arsenate adsorption on ferrihydrite: Kinetics, equilibrium, and adsorption envelopes. Environ. Sci. Technol. 32, 344349.

Reincke, T. and Barthel, D. (1997) Silica uptake kinetics of Halichondria panicea in Kiel Bight. Mar. Biol. 129, 591-593.

Reynolds, B.C., Frank, M. and Halliday, A.N. (2006) Silicon isotope fractionation during nutrient utilization in the North Pacific. Earth. Planet. Sci. Lett. 244, 431-443.

Rouxel, O., Galy, A. and Elderfield, H. (2006) Germanium isotopic variations in igneous rocks and marine sediments. Geochim. Cosmochim. Acta 70, 3387-3400.

Robinson, L., (2015). Uncalibrated Hydrographic Data acquired with a CTD in the Drake Passage during the Nathaniel B. Palmer expedition NBP1103 (2011). Integrated Earth Data Applications (IEDA). doi: http://dx.doi.org/10.1594/IEDA/317657.

Sarmiento, J.L., Gruber, N., Brzezinski, M.A. and Dunne, J.P. (2004) High-latitude controls of thermocline nutrients and low latitude biological productivity. Nature 427, 56-60.

Sarthou, G., Baker, A.R., Blain, S., Achterberg, E.P., Boye, M., Bowie, A.R., Croot, P., Laan, P., de Baar, H.J.W., Jickells, T.D. and Worsfold, P.J. (2003) Atmospheric iron deposition and sea-surface dissolved iron concentrations in the eastern Atlantic Ocean. Deep-Sea Research Part I-Oceanographic Research Papers 50, 1339-1352.

Schlitzer, R., Ocean Data View, https://odv.awi.de, 2016.

Schröder, H.C., Wang, X.H., Tremel, W., Ushijima, H. and Muller, W.E.G. (2008) Biofabrication of biosilica-glass by living organisms. Natural Product Reports 25, 455-474.

Siebert, C., Nagler, T.F. and Kramers, J.D. (2001) Determination of molybdenum isotope fractionation by double-spike multicollector inductively coupled plasma mass spectrometry. Geochem Geophy Geosy 2, art. no.-2000GC000124.

Siebert, C., Ross, A. and McManus, J. (2006) Germanium isotope measurements of hightemperature geothermal fluids using double-spike hydride generation MC-ICP-MS. Geochim. Cosmochim. Acta 70, 3986-3995.

Siebert, C., Hammond, D.E., Ross, A. and McManus, J. (2011) Germanium isotope measurements of high-temperature geothermal fluids using double-spike hydride generation MC-ICP-MS (vol 70, pg 3986, 2006). Geochim. Cosmochim. Acta 75, 6267-6269. 
Sudre, J., Garcon, V., Provost, C., Sennechael, N., Huhn, O. and Lacombe, M. (2011) Shortterm variations of deep water masses in Drake Passage revealed by a multiparametric analysis of the ANT-XXIII/3 bottle data. Deep-Sea Research Part Ii-Topical Studies in Oceanography 58, 2592-2612.

Sutton, J., Ellwood, M.J., Maher, W.A. and Croot, P.L. (2010) Oceanic distribution of inorganic germanium relative to silicon: Germanium discrimination by diatoms. Global Biogeochem. Cycles 24.

Sutton, J.N., Varela, D.E., Brzezinski, M.A. and Beucher, C.P. (2013) Species-dependent silicon isotope fractionation by marine diatoms. Geochim. Cosmochim. Acta 104, 300-309.

Treguer, P.J. and De La Rocha, C.L. (2013) The World Ocean Silica Cycle, in: Carlson, C.A., Giovannoni, S.J. (Eds.), Annual Review of Marine Science, Vol 5, pp. 477-501.

Well, R., Roether, W. and Stevens, D.P. (2003) An additional deep-water mass in Drake Passage as revealed by He-3 data. Deep-Sea Research Part I-Oceanographic Research Papers 50, 1079-1098.

Wheat, C.G. and McManus, J. (2008) Germanium in mid-ocean ridge flank hydrothermal fluids. Geochem Geophy Geosy 9.

Wille, M., Sutton, J., Ellwood, M.J., Sambridge, M., Maher, W., Eggins, S. and Kelly, M. (2010) Silicon isotopic fractionation in marine sponges: A new model for understanding silicon isotopic variations in sponges. Earth. Planet. Sci. Lett. 292, 281-289. 


\section{Figure captions}

Figure 1: Map of the Southern Ocean and Drake Passage showing the location of hydrographic stations investigated for Ge concentration and isotope composition: Sars, WAP and Burdwood Bank. Location of deep sea sponges are also represented (see map caption). The locations of water mass fronts are from Orsi et al. (2015). The map was produced using Ocean Data view (Shlitzer, 2016).

Figure 2: Recovery yield of Ge by co-precipitation with Fe-oxyhydroxide as a function of $\mathrm{pH}$ and amount of $\mathrm{Fe}$ added (in $\mathrm{mg}$ ) in seawater matrix. Experiments performed using filtered surface seawater from the Bay of Brest, with a total volume of $4 \mathrm{~L}$ for each experiments. Yield was determined by the amount of double-spike recovered and is therefore independent of blank and initial Ge present in the sample.

Figure 3: Ge concentration (squares) (a) and Ge isotope composition (squares) (b) of synthetic seawater samples obtained by doping surface coastal seawater (from Bay of Brest) with various amount of Ge standard SRM 3120a. The extrapolated $\delta^{7 / 70} \mathrm{Ge}$ value (circle) determined by the relationship in (b) is estimated to be $2.55 \pm 0.41 \%$ (2SE), undistinguishable from duplicate measurement of un-doped "Bay of Brest" internal standards (triangles). Error bars show precision at 2SE and are often smaller than the datapoint symbol.

Figure 4: Vertical profiles of Ge isotope composition $\left(\delta^{74 / 70} \mathrm{Ge}\right)$, Ge concentration (in pM), $\mathrm{Ge} / \mathrm{Si}$ ratios $(\mu \mathrm{mol} / \mathrm{mol})$ and apparent oxygen utilization (AOU) at station Sars, Southern Ocean. Dashed lines indicate the limits between the water masses, Antarctic Intermediate water (AAIW), Upper Circumpolar Deep Water (UCDW) and Low Circumpolar Deep Water (LCDW).

Figure 5: Vertical profiles of Ge isotope composition $\left(\delta^{74 / 70} \mathrm{Ge}\right)$, Ge concentration (in $\left.\mathrm{pM}\right)$, $\mathrm{Ge} / \mathrm{Si}$ ratios $(\mu \mathrm{mol} / \mathrm{mol})$ and apparent oxygen utilization (AOU) at station WAP, Southern Ocean. Dashed lines indicate the limits between the water masses, AAIW, UCDW, LCDW and Antarctic Bottom Water (AABW). 
Figure 6: Vertical profiles of Ge isotope composition $\left(\delta^{74 / 70} \mathrm{Ge}\right)$, Ge concentration (in pM), $\mathrm{Ge} / \mathrm{Si}$ ratios $(\mu \mathrm{mol} / \mathrm{mol})$ and apparent oxygen utilization (AOU) at station Burdwood Bank, Southern Ocean. Dashed lines indicate the limits between the water masses, AAIW, UCDW, LCDW and AABW.

Figure 7: Relationship between dissolved Ge and Si concentrations at all three stations. The regression line (solid thin line) is calculated from the data reported in Table 1 and 2 and is defined by $\mathrm{Ge}=0.775 \pm 0.04 * \mathrm{Si}+3.6 \pm 3.4, \mathrm{r}^{2}=0.94$. The thick dashed line corresponds to the regression line determined by Sutton et al. (2010) using a global seawater dataset and is defined by $\left.\mathrm{Ge}=0.760 \pm 0.004 * \mathrm{Si}+1.27 \pm 0.24, \mathrm{r}^{2}=0.993\right)$.

Figure 8: Ge isotope composition of deep sea sponges against (a) Si isotope composition (data from Hendry et al., 2010) and (b) Ge/Si ratios. The relationships between Ge/Si ratios and $\mathrm{Ge}$ concentration in overlying seawater is also shown (c) and compared to previously reported correlation line from Ellwood et al. (2006) defined as $\mathrm{Ge} / \mathrm{Si}=0.0031( \pm 0.0002) * \mathrm{Ge}+$ $0.0818( \pm 0.0078)$.

Figure 9: Salinity, temperature and oxygen profiles using CTD data from Robinson (2015). Thick black line represents CTD profile at WAP station, thick grey line represents CTD profile at Sars station and thin black line represents CTD profile at Burdwood Bank station. Markers correspond to discrete CTD values of seawater samples selected for Ge concentration and isotope composition (circles for WAP station, squares for SARS station and triangle for Burdwood Bank station). (a) Temperature-Salinity diagram of the three Southern Ocean stations studied covering the range of water depths sampled for Ge analysis. See text for the definition of water masses. (b) Vertical profiles of dissolved oxygen concentrations (mL/L) at the three stations. (c) Vertical profiles of salinity (psu) at the three stations.

Figure 10: $\delta^{74 / 70} \mathrm{Ge}$ vs Ge concentrations for the two stations (Sars, WAP) where surface seawater $(<1000 \mathrm{~m})$ was sampled. Water samples at depths greater than $1300 \mathrm{~m}$ at station Sars are also shown for comparison. Solid line represents a Rayleigh fractionation model with initial $\delta^{74 / 70} \mathrm{Ge}=2.4 \%$ and $\alpha_{\text {liquid-solid }}=1.0006$, the best fit for the upper $1000 \mathrm{~m}$ water column 
at station Sars. Dash line represents a Rayleigh fractionation model with initial $\delta^{74 / 70} \mathrm{Ge}=3.1$ $\% o$ and $\alpha_{\text {liquid-solid }}=1.0003$, the best fit for the upper $1000 \mathrm{~m}$ water column at station WAP and passing through the surface seawater of station Sars. 


\section{Table captions}

Table 1: Germanium concentration and isotope composition of seawater samples from Loihi (N Pacific Ocean) and Bermuda (N Atlantic Ocean) areas

Table 2: Germanium concentration and isotope composition of seawater samples from the Southern Ocean recovered during cruise NBP1103. Ancillary parameters from CTD rosette are also reported

Table 3: Germanium concentration and isotope composition of deep sea sponges. Overlying seawater composition is also reported. 
Table 1: Ge concentration and isotope composition of seawater samples from Loihi (N Pacific Ocean) and Bermuda (N Atlantic Ocean) areas

\begin{tabular}{llccccc}
\hline \multicolumn{1}{c}{ Sample * } & Station & Depth $^{\$}(\mathrm{~m})$ & $\begin{array}{c}\delta^{74 / 70} \mathrm{Ge} \\
(\%)\end{array}$ & 2SE & 2SD & Ge $(\mathrm{pM})^{\mathrm{f}}$ \\
\hline Loihi Seamount, 2014 & & & & & & \\
Loihi2014 CTD15-A, NF [1] & Shinka Deep & $4744-4653$ & 3.21 & 0.07 & $0.19(\mathrm{n}=19)$ & 113 \\
Loihi2014 CTD15-A, F [2] & Shinka Deep & $4744-4653$ & 3.14 & 0.12 & $0.19(\mathrm{n}=19)$ & 112 \\
Loihi2014 CTD18-A, NF [3] & FeMo Deep & $4744-4653$ & 2.98 & 0.06 & $0.19(\mathrm{n}=19)$ & 104 \\
Loihi2014 CTD18-A, NF [4] & FeMo Deep & $4744-4653$ & 3.00 & 0.02 & $0.19(\mathrm{n}=19)$ & 105 \\
Loihi2014 CTD17-A, NF [5] & Off plume & $1402-1341$ & 3.07 & 0.10 & $0.19(\mathrm{n}=19)$ & 96 \\
Loihi2014 CTD17-A, F [6] & Off plume & $1402-1341$ & 3.35 & 0.11 & $0.19(\mathrm{n}=19)$ & 98 \\
Loihi2014 CTD17-B, NF [7] & Off plume & $1322-959$ & 3.41 & 0.09 & $0.19(\mathrm{n}=19)$ & 88 \\
Loihi2014 CTD17-B, F [8] & Off plume & $1322-959$ & 3.29 & 0.07 & $0.19(\mathrm{n}=19)$ & 90 \\
Loihi Seamount 2009 & & & & & & \\
FeMo2009 CTD3-A, F [9] & FeMo Deep & $4900-4000$ & 3.27 & 0.06 & $0.19(\mathrm{n}=19)$ & 117 \\
FeMo2009 CTD3-21, F & FeMo Deep & 500 & 3.13 & 0.11 & $0.19(\mathrm{n}=19)$ & 86 \\
GEOTRACES Intercalibration, 2008 & & & & & & \\
GSI-70 & BATS & 2 & 3.09 & 0.26 & $0.19(\mathrm{n}=19)$ & 7 \\
GDI-88 & BATS & 2000 & 2.89 & 0.09 & $0.19(\mathrm{n}=19)$ & 24 \\
GDI-88 dup & BATS & 2000 & 2.96 & 0.18 & $0.19(\mathrm{n}=19)$ & 24 \\
\hline
\end{tabular}

* : composite samples obtained by mixing several samples in equal proportion are referred as number in brackets: [1] niskins $4+7+12+16$; [2] niskins $1+5+9+14$; [3] niskins $4+7+12+16$ [4] duplicate of [3]; [5] niskins 4+6+8+10; [6] niskins 3+5+7+9; [7] niskins $12+14+16+18$; [8] niskins $11+13+15+17$; [9] niskins 3+7

$\$$ : Depth range correspond to the top-bottom depths of the pooled niskin bottles $f$ : Ge concentration determined by isotope dillution with precision better than $0.1 \%$ at $2 \mathrm{SD}$ 2SE determined by calculating the two standard error of the 5 blocks of 6 measurements each 2SD determined by calculating the two standard deviation of all NIST 3120a standards measured during the same analytical session 
Table 2: Ge concentration and isotope composition of seawater samples from the Southern Ocean recovered during cruise NBP1103. Ancillary parameters from CTD rosette are also reported

\begin{tabular}{|c|c|c|c|c|c|c|c|c|c|c|c|c|c|}
\hline Sample/ station & $\begin{array}{l}\text { Depth } \\
\text { (m) }\end{array}$ & $\begin{array}{l}\text { Water } \\
\text { masses }\end{array}$ & $\delta^{74 / 70} \mathrm{Ge}(\% \circ)$ & 2SE & $2 S D$ & $\begin{array}{c}\mathrm{Ge} \\
(\mathrm{pM})\end{array}$ & $\mathrm{Si}(\mu \mathrm{M})$ & $\begin{array}{c}\mathrm{Ge} / \mathrm{Si} \\
(\mathrm{mol} / \mathrm{mol})\end{array}$ & $\begin{array}{l}\text { Salinity } \\
\text { (psu) }\end{array}$ & $\begin{array}{c}\text { Temperature } \\
\left({ }^{\circ} \mathrm{C}\right)\end{array}$ & $\begin{array}{l}\text { Oxygen } \\
(\mathrm{ml} / \mathrm{l})\end{array}$ & $\begin{array}{l}\text { AOU* } \\
(\mathrm{ml} / \mathrm{l})\end{array}$ & $\begin{array}{c}\text { Fluorescence } \\
\text { (ug/l) }\end{array}$ \\
\hline \multicolumn{14}{|c|}{ Station SARS $\left(59.753^{\circ} \mathrm{S}, 69.057^{\circ} \mathrm{W}\right)$} \\
\hline CTD100-24 & 3 & & 3.71 & 0.21 & $0.17(n=28)$ & 15 & 13 & 1.11 & 33.97 & 2.81 & 6.88 & 0.53 & 0.20 \\
\hline CTD100-22 & 299 & AAIW & 3.07 & 0.09 & $0.10(n=11)$ & 29 & 31 & 0.92 & 34.10 & 2.18 & 5.86 & 1.55 & 0.02 \\
\hline CTD100-20 & 651 & AAIW & 2.71 & 0.18 & $0.10(n=11)$ & 53 & 65 & 0.82 & 34.42 & 2.72 & 3.96 & 3.46 & 0.04 \\
\hline CTD100-18 & 801 & AAIW & 2.85 & 0.17 & $0.10(n=11)$ & 57 & 66 & 0.87 & 34.49 & 2.59 & 3.76 & 3.66 & 0.04 \\
\hline CTD100-16 & 999 & UCDW/mix & 2.62 & 0.04 & $0.10(n=11)$ & 63 & 80 & 0.79 & 34.57 & 2.44 & 3.66 & 3.76 & 0.05 \\
\hline CTD100-14 & 1301 & UCDW & 3.28 & 0.07 & $0.08(n=4)$ & 63 & 89 & 0.70 & 34.66 & 2.25 & 3.71 & 3.70 & 0.04 \\
\hline CTD100-12 & 1500 & UCDW & 3.23 & 0.05 & $0.17(n=28)$ & 74 & 89 & 0.83 & 34.69 & 2.12 & 3.79 & 3.63 & 0.04 \\
\hline CTD100-10 & 1751 & UCDW & 3.21 & 0.03 & $0.17(n=28)$ & 79 & 95 & 0.83 & 34.71 & 1.96 & 3.85 & 3.57 & 0.04 \\
\hline CTD100-8 & 2000 & LCDW & 3.20 & 0.07 & $0.08(n=4)$ & 84 & 102 & 0.82 & 34.72 & 1.77 & 3.89 & 3.53 & 0.04 \\
\hline \multicolumn{3}{|c|}{ CTD100-8 (duplicate) } & 3.18 & 0.14 & $0.21(n=18)$ & & & & & & & & \\
\hline CTD100-6 & 2300 & LCDW & 3.21 & 0.05 & $0.08(n=4)$ & 85 & 107 & 0.80 & 34.72 & 1.56 & 4.02 & 3.40 & 0.04 \\
\hline CTD100-4 & 2600 & LCDW & 3.06 & 0.05 & $0.21(n=18)$ & 91 & 112 & 0.81 & 34.72 & 1.39 & 4.10 & 3.32 & 0.03 \\
\hline CTD100-2 & 3100 & LCDW & 3.02 & 0.04 & $0.21(n=18)$ & 93 & 126 & 0.74 & 34.71 & 0.95 & 4.26 & 3.16 & 0.05 \\
\hline \multicolumn{14}{|c|}{ Station WAP off slope $\left(62.067^{\circ} \mathrm{S}, 62.583^{\circ} \mathrm{W}\right)$} \\
\hline CTD72-24 & 5 & & 3.50 & 0.14 & $0.21(n=18)$ & 36 & 44 & 0.82 & 33.85 & -0.15 & 7.31 & 0.69 & 0.33 \\
\hline CTD72-20 & 601 & UCDW & 3.30 & 0.09 & $0.08(n=4)$ & 81 & 97 & 0.84 & 34.72 & 1.65 & 3.93 & 4.07 & 0.04 \\
\hline CTD72-18 & 800 & UCDW & 3.11 & 0.08 & $0.21(n=18)$ & 78 & 102 & 0.76 & 34.73 & 1.49 & 4.05 & 3.95 & 0.04 \\
\hline \multicolumn{3}{|c|}{ CTD72-18 (duplicate) } & 3.27 & 0.08 & $0.08(n=4)$ & & & & & & & & \\
\hline CTD72-16 & 1001 & LCDW & 3.33 & 0.08 & $0.08(n=4)$ & 105 & 102 & 1.03 & 34.73 & 1.31 & 4.11 & 3.89 & 0.04 \\
\hline CTD72-12 & 2000 & AABW & 3.15 & 0.08 & $0.21(n=18)$ & 104 & 124 & 0.84 & 34.71 & 0.70 & 4.34 & 3.66 & 0.04 \\
\hline \multicolumn{3}{|c|}{ CTD72-12 (duplicate) } & 3.36 & 0.09 & $0.17(n=28)$ & & & & & & & & \\
\hline CTD72-10 & 2499 & AABW & 3.32 & 0.04 & $0.17(n=28)$ & 106 & 131 & 0.81 & 34.70 & 0.52 & 4.40 & 3.60 & 0.04 \\
\hline \multicolumn{3}{|c|}{ CTD72-10 (duplicate) } & 3.34 & 0.06 & $0.21(n=18)$ & & & & & & & & \\
\hline CTD72-6 & 3500 & AABW & 3.11 & 0.10 & $0.17(n=28)$ & 94 & 126 & 0.74 & 34.69 & 0.38 & 4.55 & 3.45 & 0.05 \\
\hline CTD72-2 & 4719 & AABW & 3.16 & 0.09 & $0.17(n=28)$ & 99 & 127 & 0.78 & 34.68 & 0.42 & 4.54 & 3.46 & 0.04 \\
\hline \multicolumn{14}{|c|}{ Station Burdwood Bank $\left(55.053^{\circ} \mathrm{S}, 62.099^{\circ} \mathrm{W}\right)$} \\
\hline CTD21-18 & 301 & AAIW & n.d. & & & n.d. & 9 & n.d. & 34.09 & 4.58 & 6.11 & 0.79 & 0.13 \\
\hline CTD21-16 & 501 & AAIW & 3.11 & 0.10 & $0.17(n=28)$ & 16 & $27^{\mathrm{f}}$ & 0.61 & 34.15 & 4.34 & 5.67 & 1.23 & 0.00 \\
\hline CTD21-14 & 801 & AAIW & 3.00 & 0.07 & $0.10(n=11)$ & 30 & 36 & 0.84 & 34.27 & 3.68 & 4.64 & 2.27 & 0.02 \\
\hline CTD21-12 & 1400 & UCDW/mix & 3.01 & 0.05 & $0.10(n=11)$ & 64 & $82^{\mathrm{f}}$ & 0.78 & 34.52 & 2.67 & 3.41 & 3.50 & 0.04 \\
\hline CTD21-10 & 1750 & UCDW & 2.87 & 0.09 & $0.10(n=11)$ & 73 & 86 & 0.86 & 34.62 & 2.36 & 3.39 & 3.51 & 0.04 \\
\hline CTD21-4 & 3251 & LCDW & 2.44 & 0.06 & $0.10(n=11)$ & 88 & n.d. & n.d. & 34.72 & 1.41 & 3.98 & 2.93 & 0.04 \\
\hline CTD21-2 & 4111 & AABW & 2.97 & 0.08 & $0.21(n=18)$ & 100 & 114 & 0.88 & 34.71 & 1.03 & 4.17 & 2.73 & 0.04 \\
\hline
\end{tabular}

* AOU $=\left[\mathrm{O}_{2}\right]_{\text {sat }}-\left[\mathrm{O}_{2}\right]_{\text {in situ }}$ with $\left[\mathrm{O}_{2}\right]_{\text {sat }}$ calculated from Benson and Krause 1984

\$ water masses: AAIW (Antarctic Intermediate Water); LCDW (Lower Circumpolar Deep Water); AABW (Antarctic Bottom Water); UCDW (Upper Circumpolar Deep Water) n.d. : not determined

f Si concentration data extrapolated from Hendry et al. (2010) in nearby locations (cruise NBP0805, 2008).

2SE determined by calculating the two standard error of the 5 blocks of 6 measurements each

2SD determined by calculating the two standard deviation of all NIST 3120a standards measured during the same analytical session 
Table 3: Ge concentration and isotope composition of deep sea sponges. Overlying seawater composition is also reported.

\begin{tabular}{|c|c|c|c|c|c|c|c|c|c|c|c|c|c|c|c|c|c|c|c|}
\hline Sample/Area & $\begin{array}{l}\text { Lat } \\
\left({ }^{\circ} \mathrm{S}\right) \\
\end{array}$ & $\begin{array}{l}\text { Long } \\
\left({ }^{\circ} \mathrm{W}\right) \\
\end{array}$ & $\begin{array}{l}\text { Depth } \\
*(\mathrm{~m}) \\
\end{array}$ & $\begin{array}{c}\delta^{74 / 70} \mathrm{Ge} \\
(\% \circ) \\
\end{array}$ & $2 \mathrm{SE}$ & $2 S D$ & $\begin{array}{c}{[\mathrm{Ge}]} \\
(\mathrm{ppm})\end{array}$ & $\begin{array}{c}\mathrm{Ge} / \mathrm{Si} \\
(\mathrm{mmol} / \mathrm{mol})\end{array}$ & $\begin{array}{l}\delta^{30} \mathrm{Si} \\
(\% \circ)\end{array}$ & $S p^{\$}$ & $\begin{array}{c}\text { Temp } \\
\left({ }^{\circ} \mathrm{C}\right) \\
\end{array}$ & $\begin{array}{l}\text { Salinity } \\
\text { (psu) }\end{array}$ & $\mathrm{pH}$ & $\begin{array}{c}\mathrm{Si} \\
(\mathrm{mM}) \\
\end{array}$ & $\begin{array}{c}\mathrm{Ge} \\
(\mathrm{nM})\end{array}$ & $\begin{array}{c}\delta^{74 / 70} \mathrm{Ge} \\
(\% \circ) \subseteq\end{array}$ & $2 \mathrm{SE}$ & $\begin{array}{c}\Delta^{74 / 70} \mathrm{Ge}_{\text {opal- }} \\
\quad \mathrm{sw}(\% \mathrm{o}) \\
\end{array}$ & $2 \mathrm{SE}$ \\
\hline & \multicolumn{10}{|c|}{ sponges } & \multicolumn{7}{|c|}{ seawater } & & \\
\hline \multicolumn{20}{|l|}{ Burdwood Bank } \\
\hline NBP0805-TB1-11 & 54.48 & 62.18 & 320 & 2.24 & 0.04 & $0.10(n=31)$ & 0.13 & 0.109 & -1.69 & {$[1]$} & 4.3 & 34.2 & 7.96 & 12.0 & 8.4 & 3.11 & 0.10 & -0.87 & 0.11 \\
\hline NBP0805-TB1-3 & 54.48 & 62.18 & 320 & 2.19 & 0.05 & $0.10(n=31)$ & 0.16 & 0.132 & -0.70 & {$[2]$} & 4.3 & 34.2 & 7.96 & 12.0 & 8.4 & 3.11 & 0.10 & -0.92 & 0.11 \\
\hline NBP0805-TB1-6 & 54.48 & 62.18 & 320 & 2.13 & 0.04 & $0.10(n=31)$ & 0.19 & 0.156 & -1.01 & {$[3]$} & 4.3 & 34.2 & 7.96 & 12.0 & 8.4 & 3.11 & 0.10 & -0.98 & 0.11 \\
\hline NBP0805-TB4-24 & 54.74 & 62.21 & 816 & 1.79 & 0.05 & $0.10(n=31)$ & 0.18 & 0.151 & -2.92 & {$[2]$} & 3.1 & 34.4 & 7.80 & 56.0 & 39.2 & 3.00 & 0.07 & -1.21 & 0.09 \\
\hline NBP0805-TB4-3 & 54.74 & 62.21 & 816 & 2.22 & 0.04 & $0.10(n=31)$ & 0.20 & 0.167 & -1.55 & {$[2]$} & 3.1 & 34.4 & 7.80 & 56.0 & 39.2 & 3.00 & 0.07 & -0.78 & 0.08 \\
\hline NBP0805-TB4-3 & 54.74 & 62.21 & 816 & 2.28 & 0.03 & $0.10(n=31)$ & 0.23 & 0.186 & & & 3.1 & 34.4 & 7.80 & 56.0 & 39.2 & 3.00 & 0.07 & -0.72 & 0.08 \\
\hline \multicolumn{20}{|l|}{ Drake Passage } \\
\hline NBP0805-DR35-111 & 59.72 & 68.88 & 695 & 2.07 & 0.04 & $0.10(n=31)$ & 0.15 & 0.124 & -2.86 & {$[2]$} & 2.4 & 34.6 & 7.80 & 70.0 & 49.0 & 2.71 & 0.18 & -0.64 & 0.18 \\
\hline NBP0805-DR35-111 & 59.72 & 68.88 & 695 & 2.14 & 0.07 & $0.10(n=31)$ & 0.15 & 0.123 & -2.86 & {$[2]$} & 2.4 & 34.6 & 7.80 & 70.0 & 49.0 & 2.71 & 0.18 & -0.57 & 0.19 \\
\hline NBP0805-DR40-47 & 59.73 & 68.93 & 1323 & 2.33 & 0.08 & $0.10(n=31)$ & 0.18 & 0.151 & -2.92 & {$[4]$} & 1.9 & 34.7 & 7.72 & 94.0 & 65.8 & 3.28 & 0.07 & -0.95 & 0.10 \\
\hline NBP0805-TO3-100 & 60.56 & 65.97 & 802 & 2.11 & 0.03 & $0.10(n=31)$ & 0.20 & 0.167 & -3.06 & {$[2]$} & 2.4 & 34.6 & 7.80 & 75.0 & 52.5 & 2.85 & 0.17 & -0.74 & 0.17 \\
\hline NBP0805-TO3-111 & 60.56 & 65.97 & 802 & 1.79 & 0.02 & $0.10(n=31)$ & 0.25 & 0.209 & -3.01 & {$[2]$} & 2.4 & 34.6 & 7.80 & 75.0 & 52.5 & 2.85 & 0.17 & -1.06 & 0.17 \\
\hline \multicolumn{20}{|l|}{ Elephant Island } \\
\hline NBP0805-TO1-27 & 61.25 & 62.21 & 418 & 2.15 & 0.05 & $0.10(n=31)$ & 0.37 & 0.302 & -3.83 & [5] & 1.9 & 34.7 & 7.71 & 90.0 & 63.0 & 3.11 & 0.08 & -0.96 & 0.09 \\
\hline \multicolumn{20}{|l|}{ Scotia Sea } \\
\hline NBP0805-DR13-47 & 59.50 & 42.50 & 2287 & 2.45 & 0.09 & $0.10(n=31)$ & 0.16 & 0.129 & -3.20 & [4] & 1.J & 35.0 & 7.70 & 110.0 & 77.0 & n.d. & & n.d. & \\
\hline NBP0805-DR16-47 & 61.10 & 56.45 & 1000 & 2.11 & 0.02 & $0.10(n=31)$ & 0.35 & 0.286 & -4.13 & [4] & 1.5 & 34.7 & 7.76 & 96.0 & 67.2 & n.d. & & n.d. & \\
\hline
\end{tabular}

$*$ middle of depth range

\$ sponge species identification: [1] Unidentified Hexactinellid; [2] Unidentified Demosponge; [3] Mycalidae; [4] Aceolocalyx; [5] Rosella

$f$ data taken from the nearest (location and depth) seawater samples in Table 2

2SE determined by calculating the two standard error of the 5 blocks of 6 measurements each

2SD determined by calculating the two standard deviation of all NIST 3120a standards measured during the same analytical session

n.d. not determined 


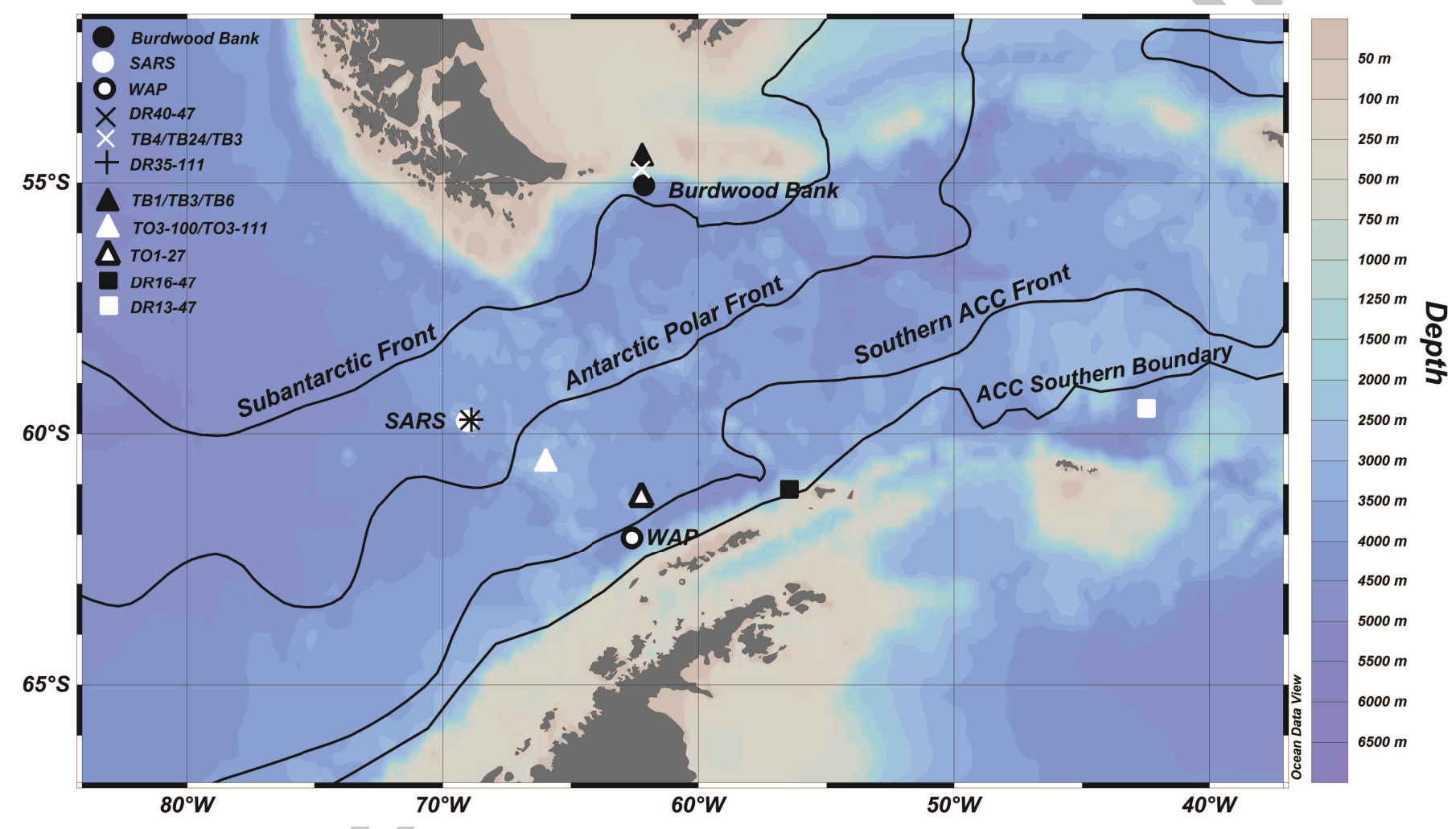

Figure 1 


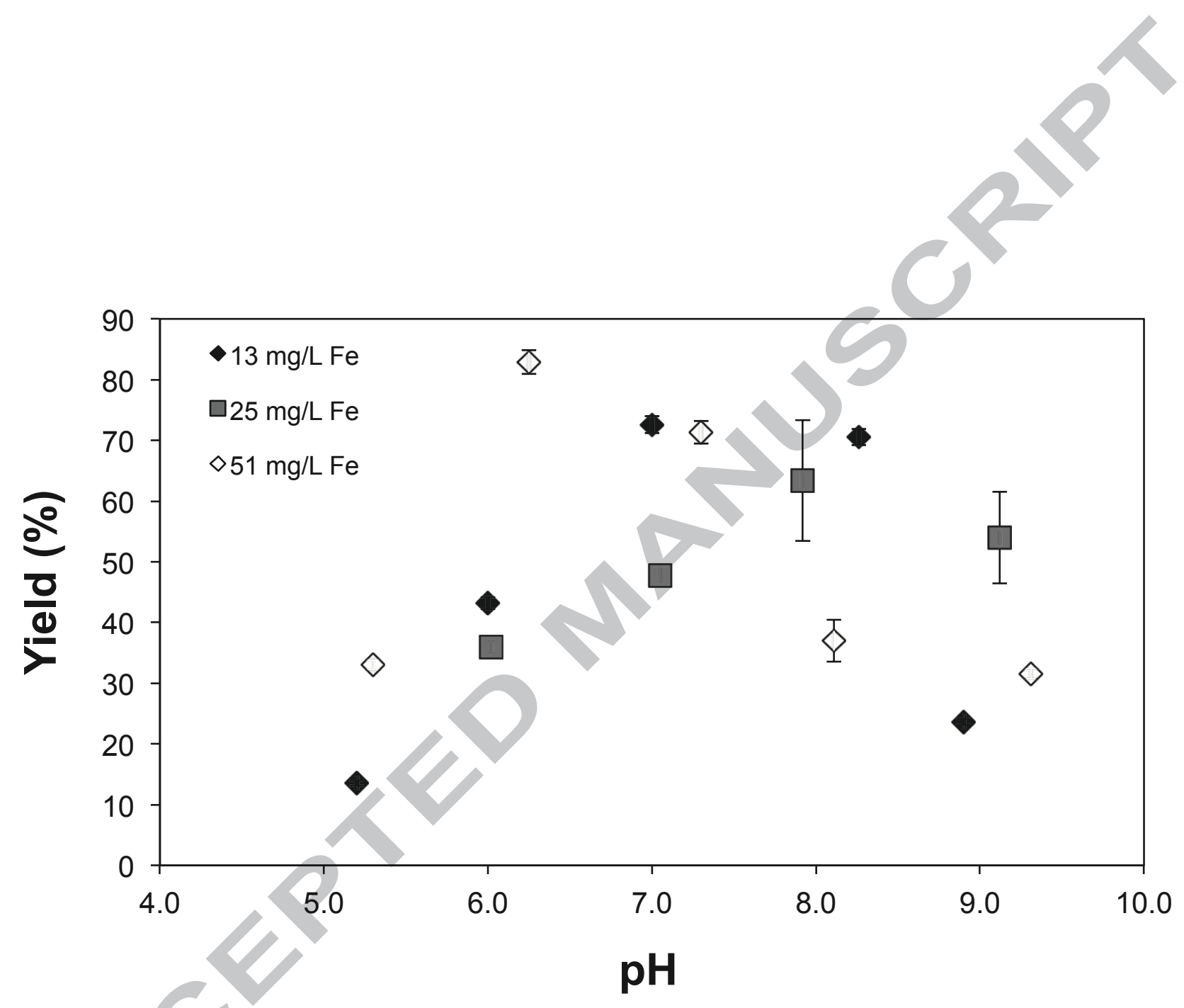

Figure 2 

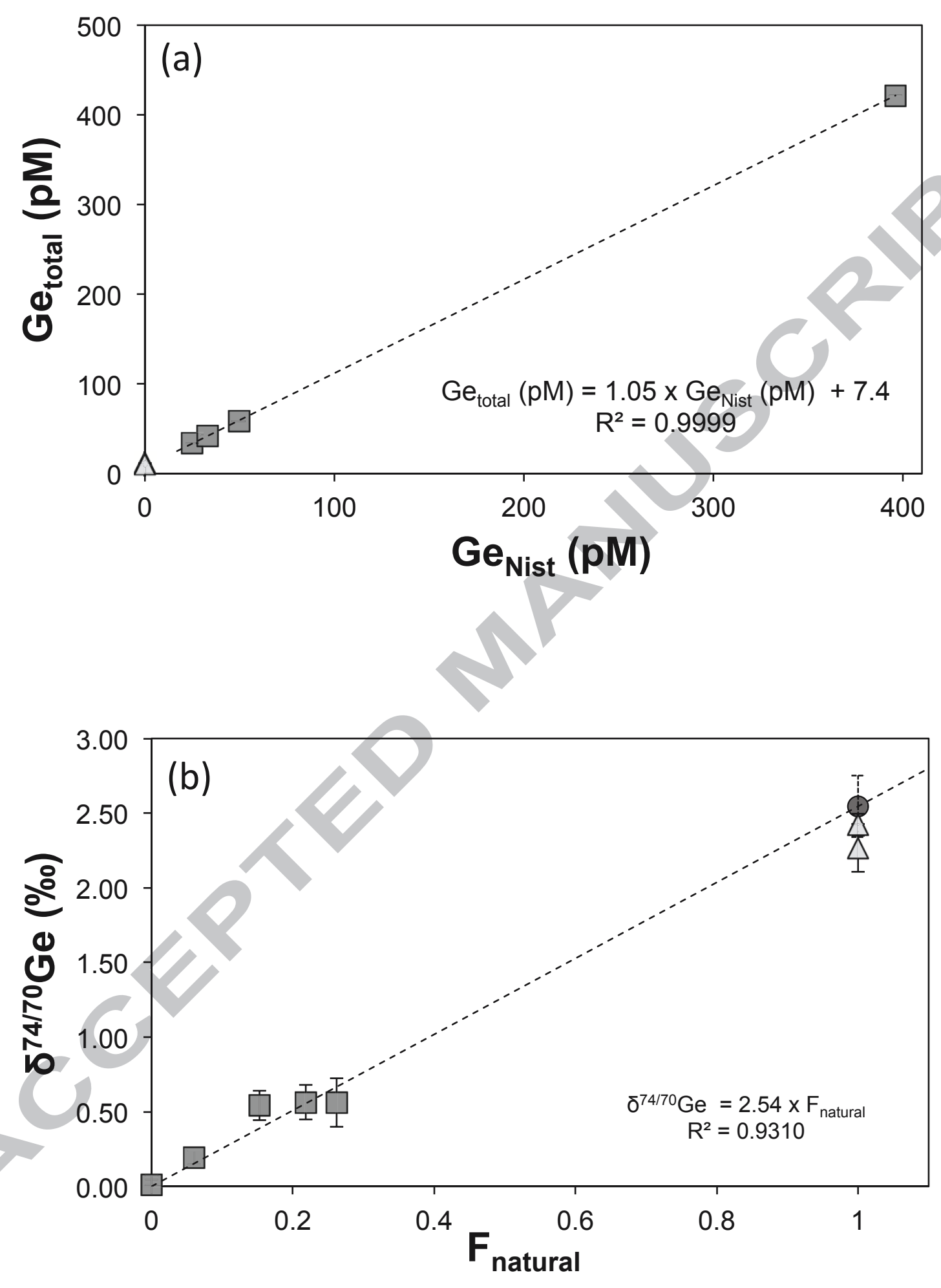

Figure 3 


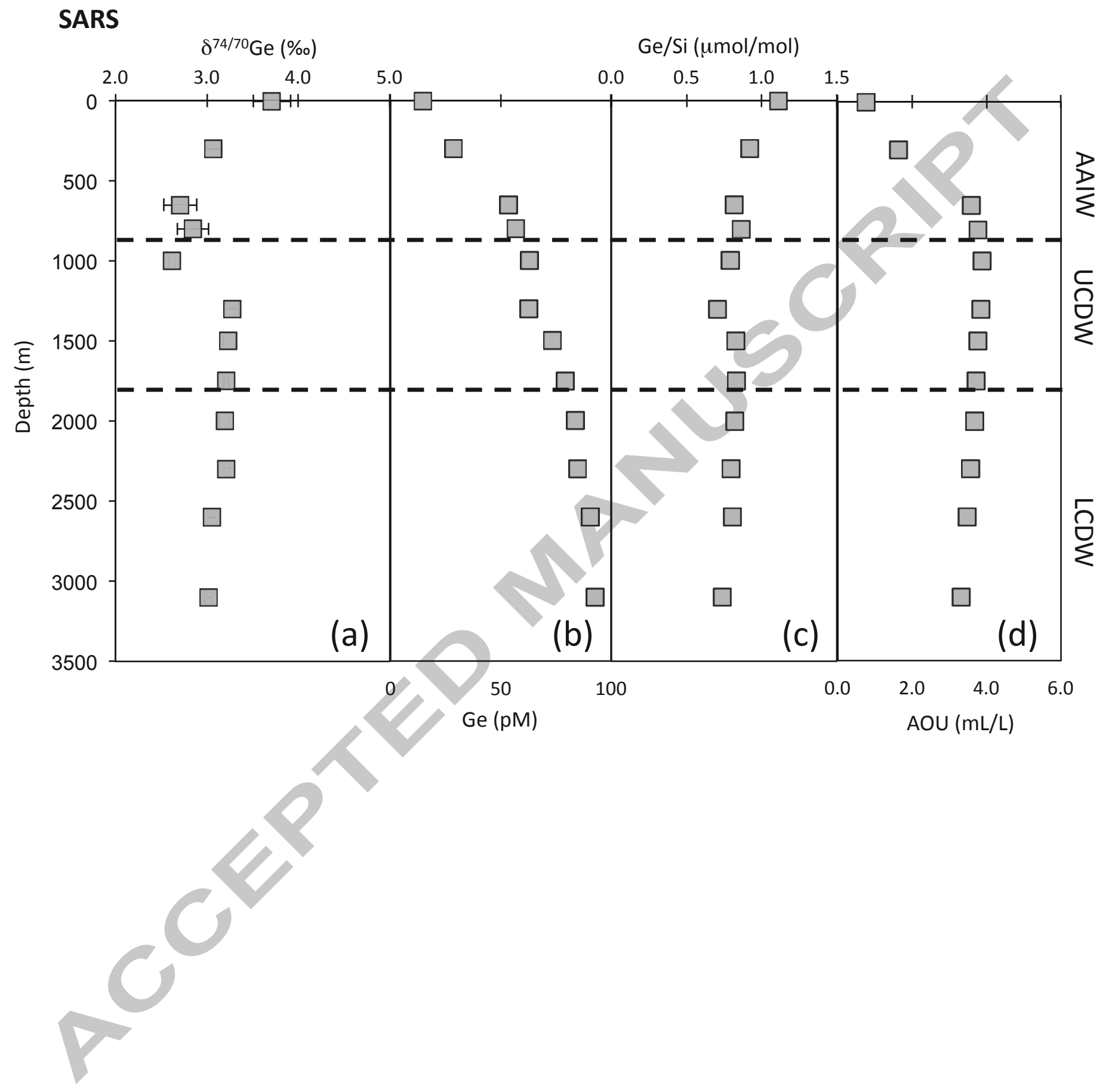

Figure 4 


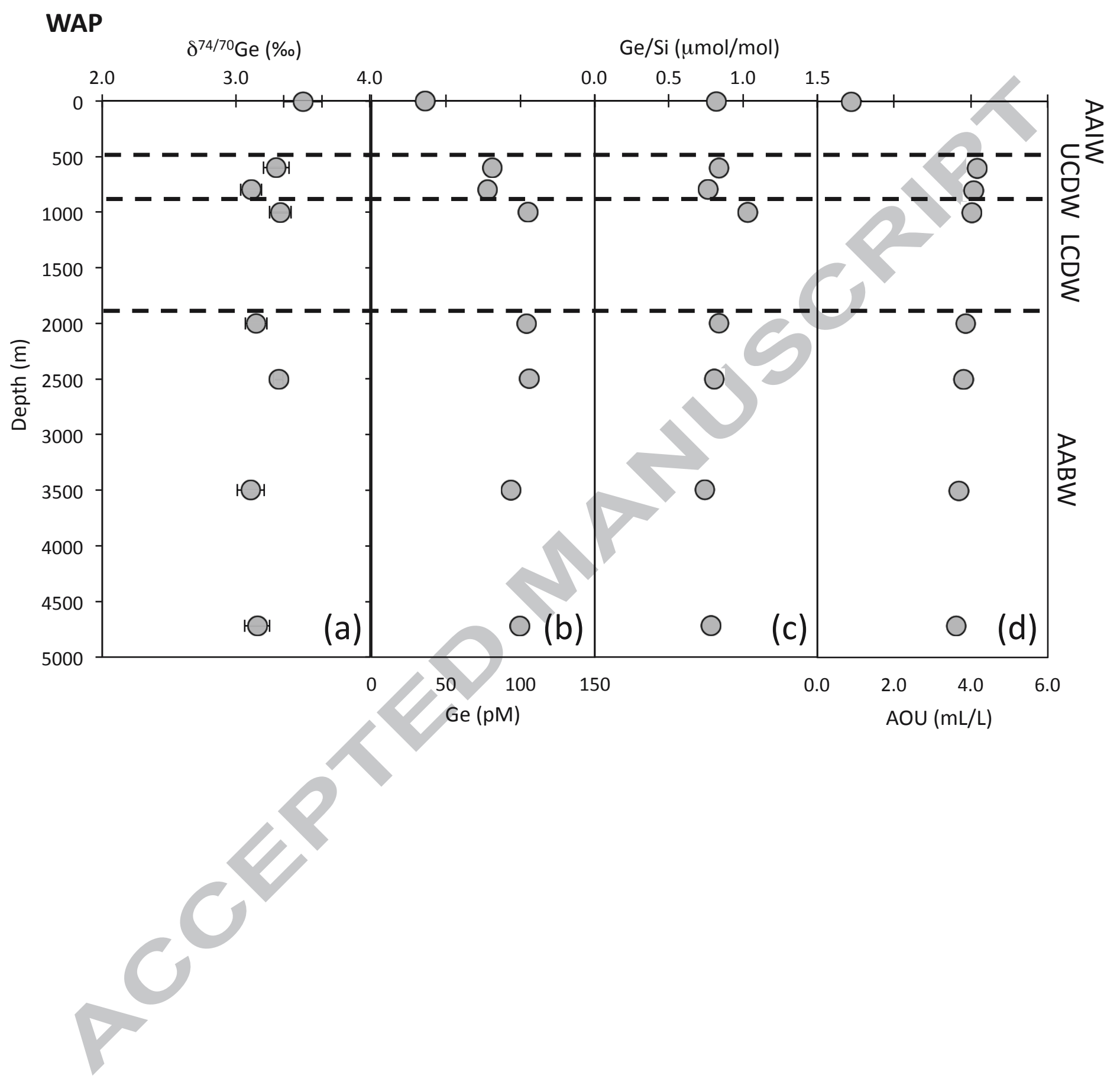

Figure 5 


\section{Burdwood Bank}

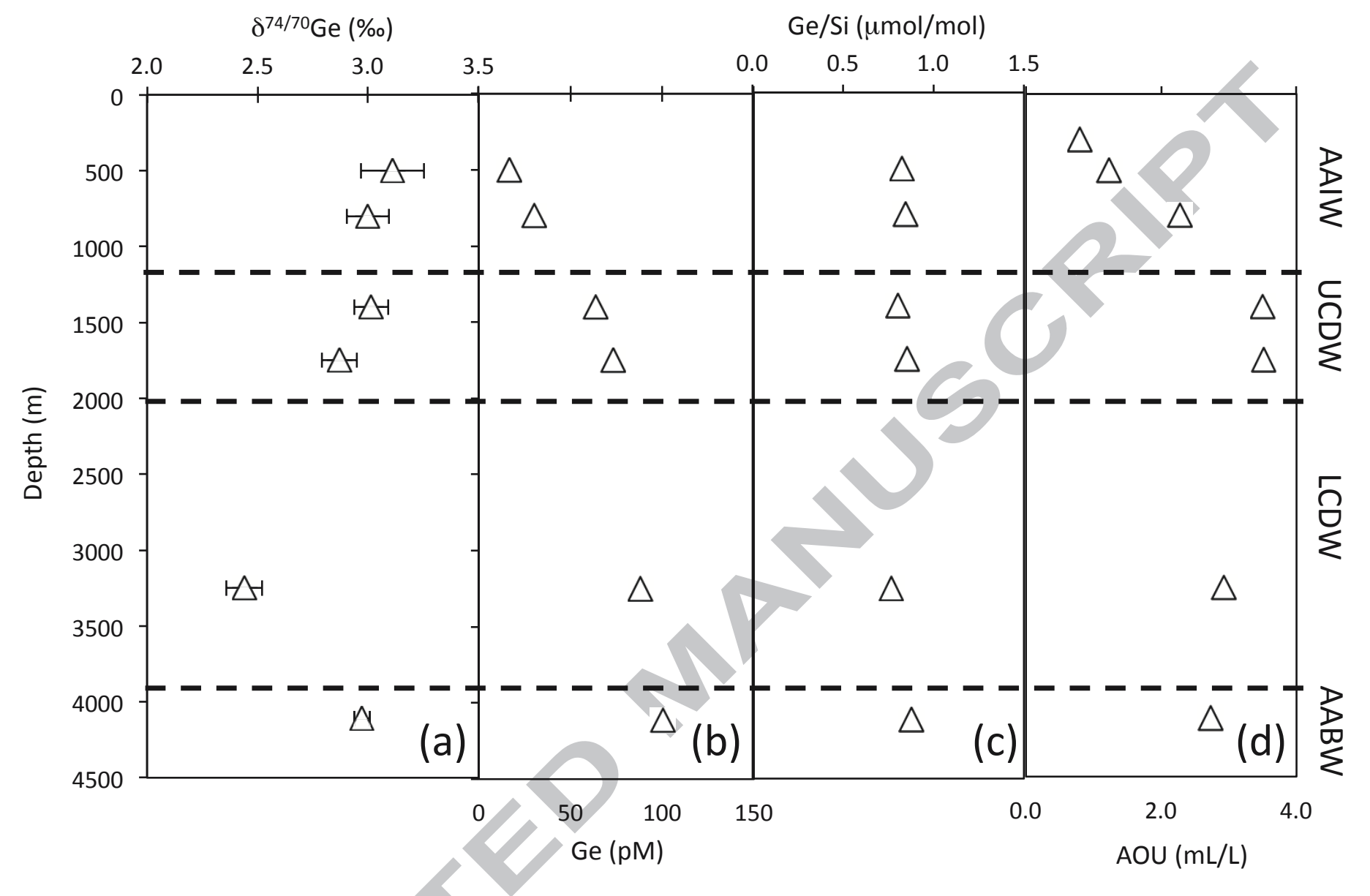

Figure 6 


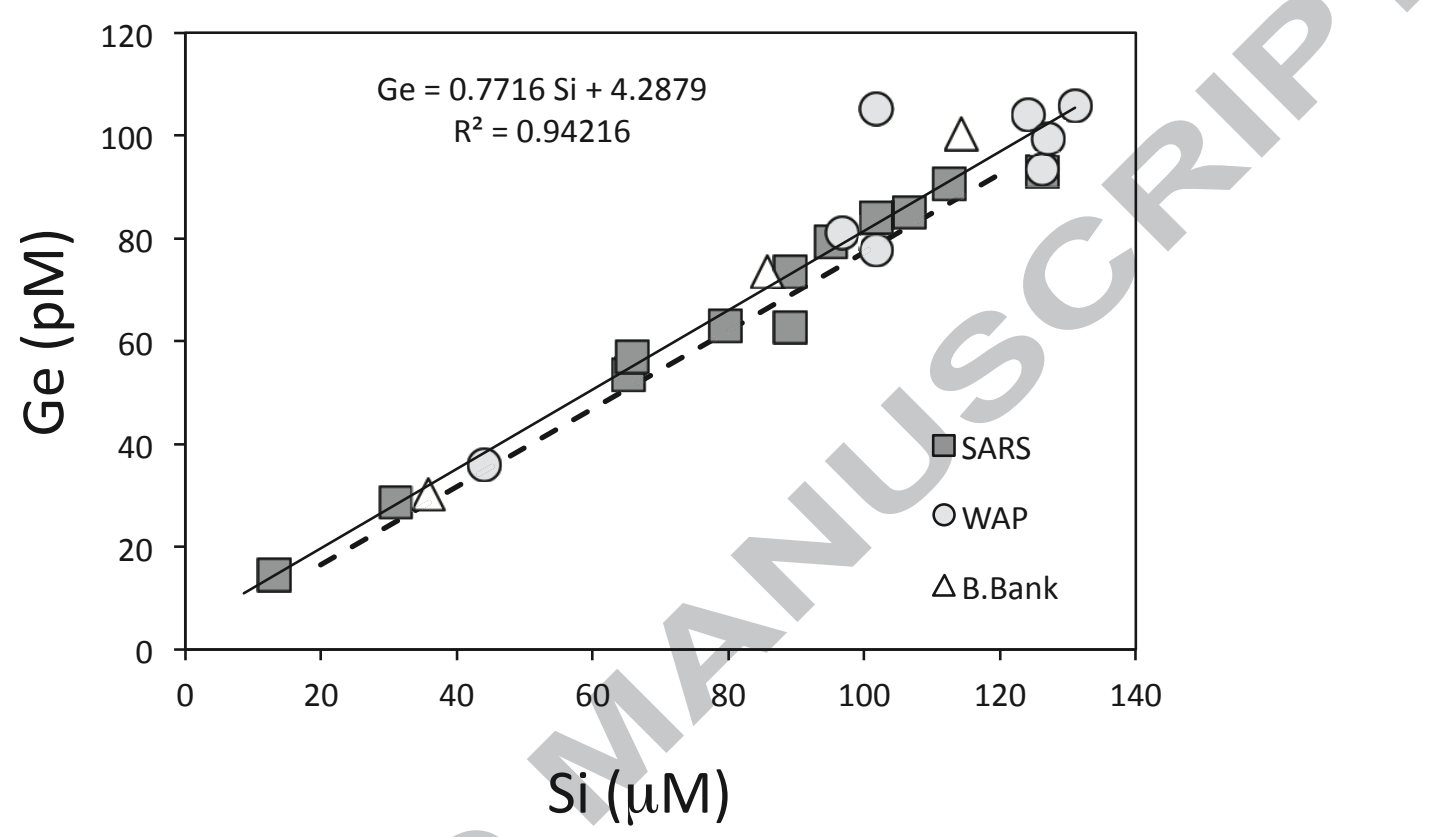

Figure 7 

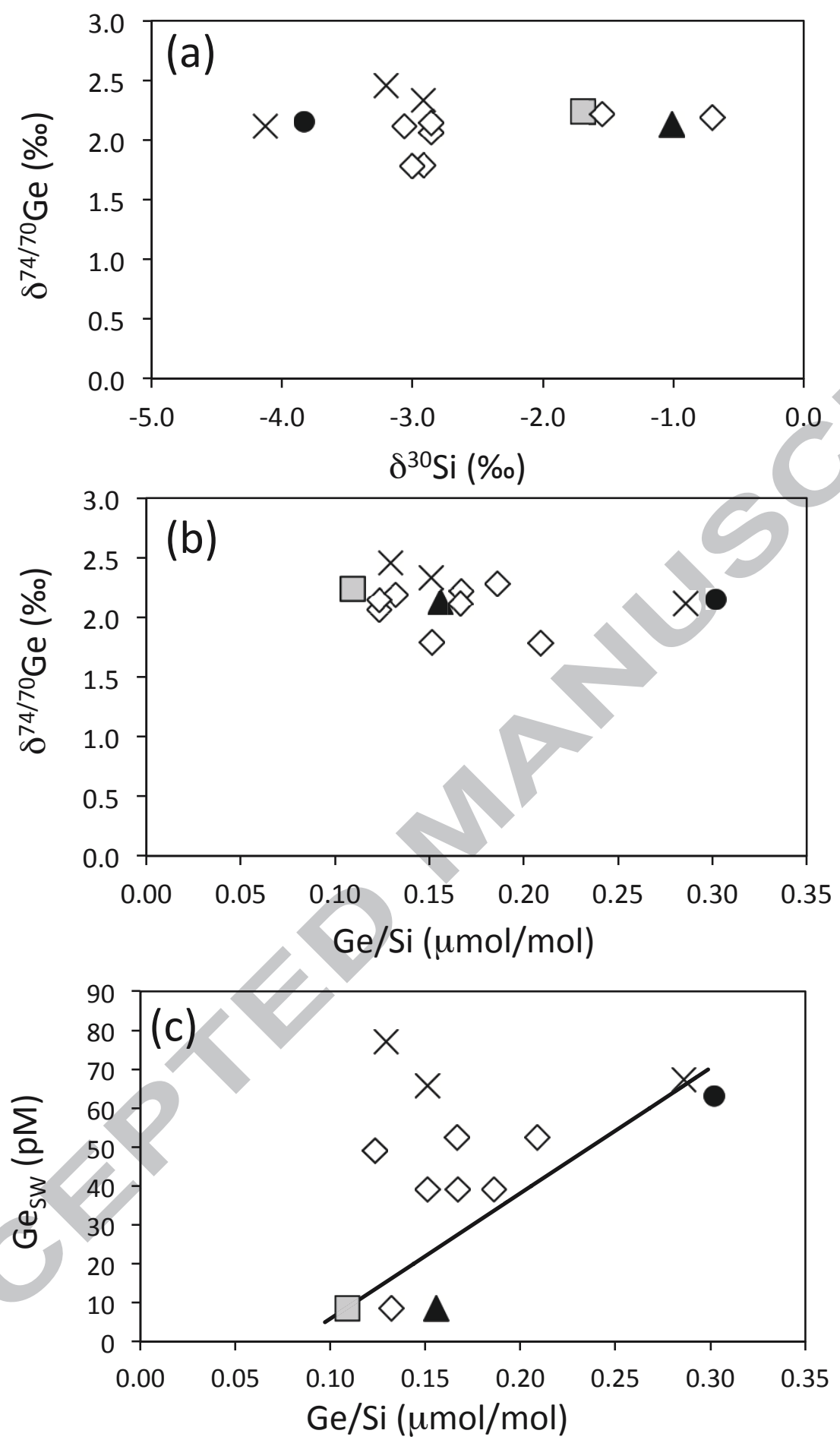

$\square$ Unidentified Hexactinellid $\diamond$ Unidentified Demosponge
$\Delta$ Mycalidae
$x$ Acoelocalyx
- Rosella

Figure 8 


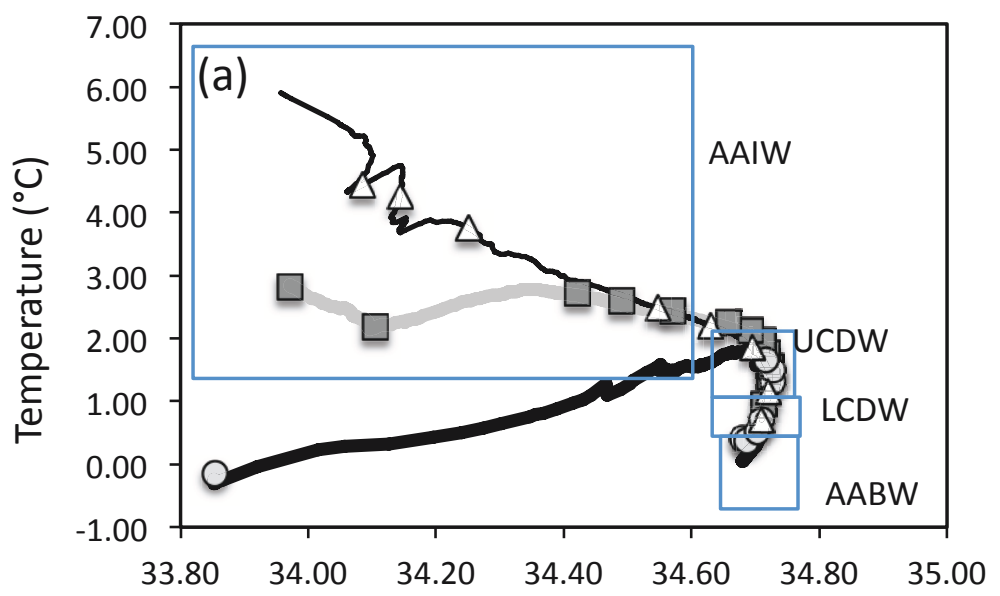

Salinity (psu)

Oxygen $(\mathrm{mL} / \mathrm{L})$

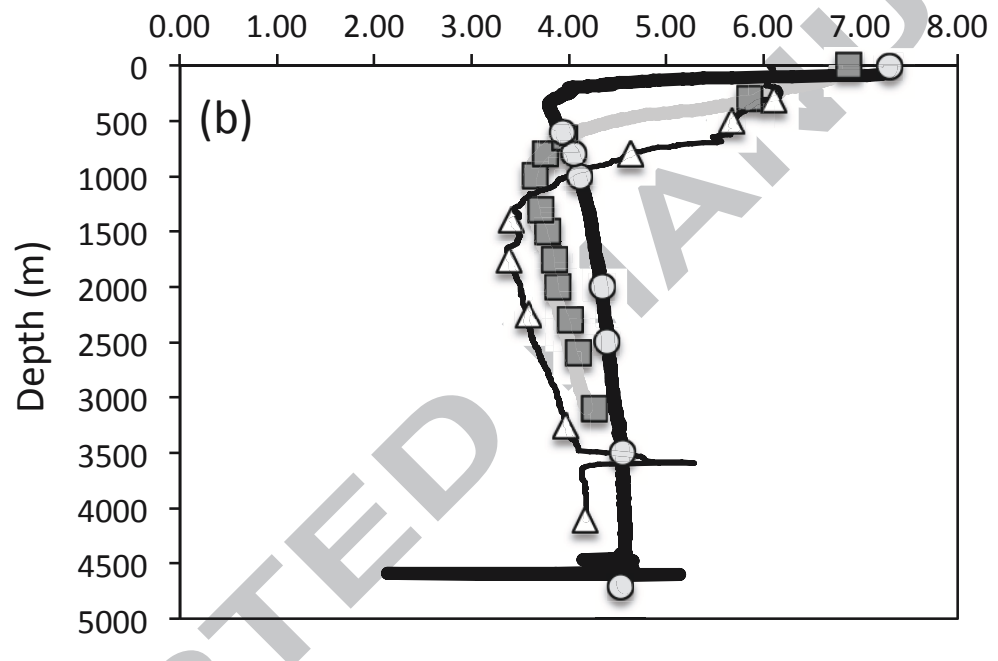

Salinity (psu)

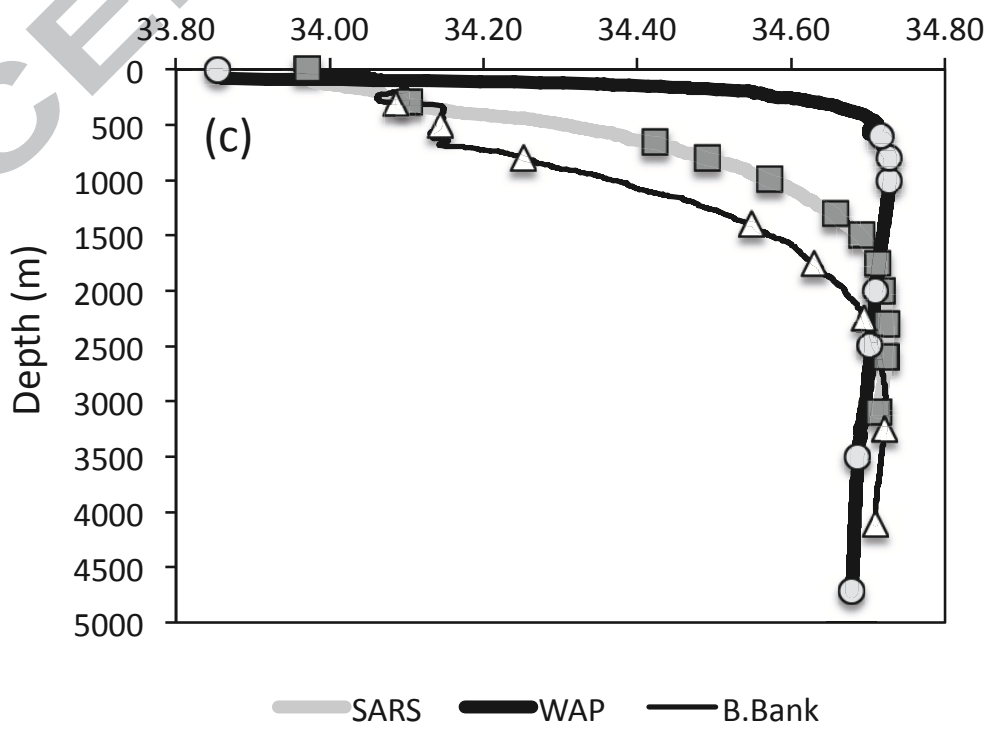

Figure 9 


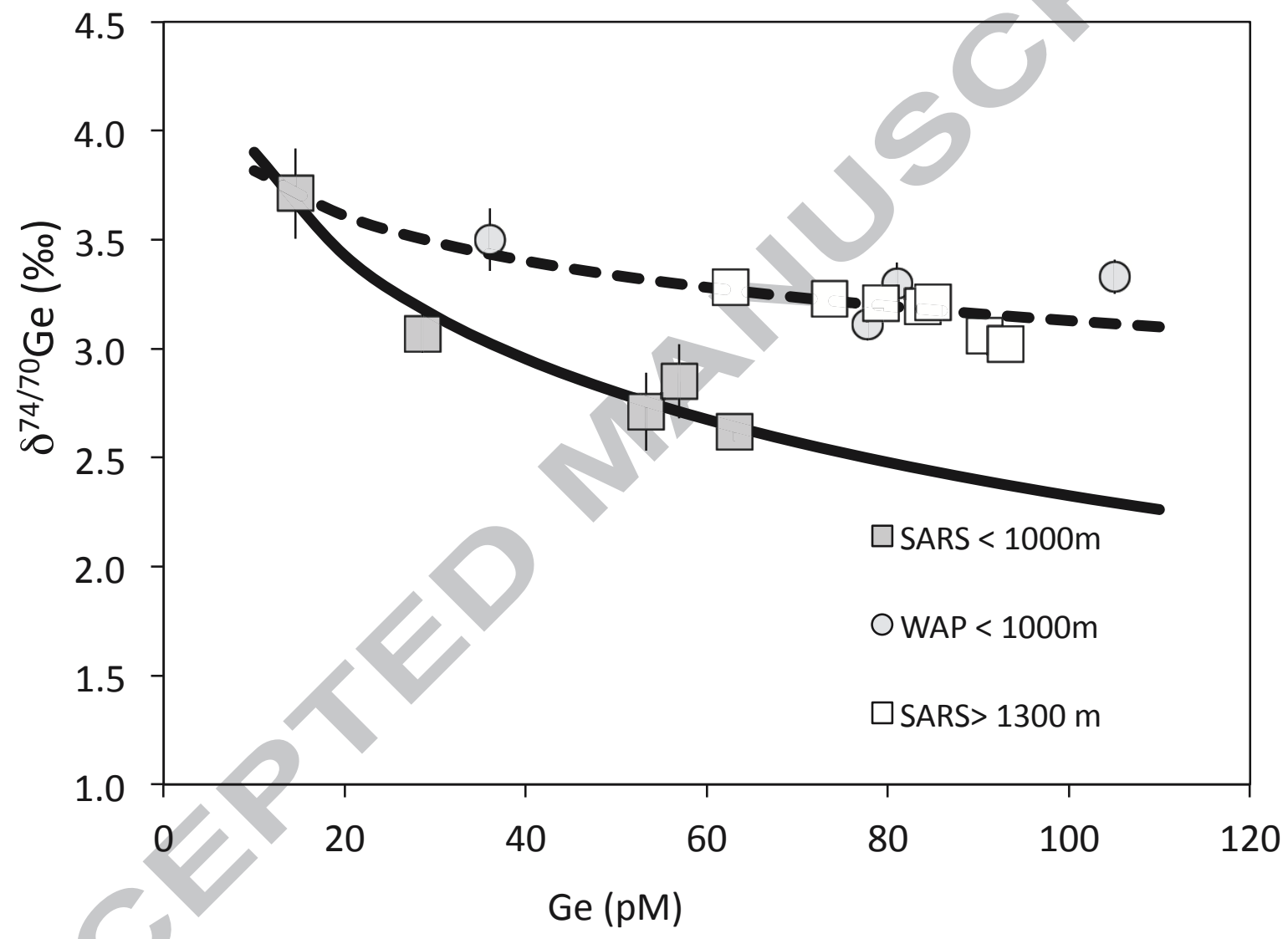

Figure 10 